Supporting Information for:

\title{
A Nickel-Doped Dehydrobenzoannulene-Based Two- Dimensional Covalent Organic Framework for the Reductive Cleavage of Inert Aryl C-S Bonds
}

W. Karl Haug, Eric R. Wolfson, Blake T. Morman, Christine M. Thomas,

Psaras L. McGrier*

Department of Chemistry \& Biochemistry, The Ohio State University, Columbus, Ohio, 43210

Table of Contents

\begin{tabular}{|c|c|c|}
\hline A. & Materials & S2 \\
\hline B. & Instrumentation and Methods & S2 \\
\hline C. & Synthetic Methods & S3 \\
\hline D. & FT-IR Spectra & S6 \\
\hline E. & Experimental \& Simulated PXRD Patterns & S6 \\
\hline F. & COF Stability Studies & S9 \\
\hline G. & Solid-State NMR Spectra & S10 \\
\hline H. & BET Surface Area Plots & S12 \\
\hline I. & TGA Profile & S13 \\
\hline J. & SEM Micrographs & S14 \\
\hline K. & XPS Spectra & S15 \\
\hline L. & $\begin{array}{c}\text { Ni-Catalyzed Reductive Cleavage of Aryl } \\
\text { Methyl Thioethers }\end{array}$ & S17 \\
\hline M. & Recyclability of Ni-DBA-2D-COF & S19 \\
\hline N. & Leaching Studies & $\mathbf{S 2 1}$ \\
\hline $\mathbf{O}$. & Mechanistic Investigations & S22 \\
\hline P. & GC-FID Chromatographs & $\mathbf{S 2 8}$ \\
\hline
\end{tabular}




\section{A. Materials}

Unless stated otherwise, all reagents were purchased from commercial sources and used without further purification. Tetrahydrofuran and methanol were purified by distillation over sodium and $\mathrm{CaH}_{2}$, respectively. Toluene and $\mathrm{CCl}_{4}$ were dried over $3 \AA \mathrm{MS}$ for $24 \mathrm{~h}$ and degassed by bubbling through $\mathrm{N}_{2}$. Dimethylformamide was purified by passage over activated alumina.

\section{B. Instrumentation and Methods}

Infrared spectra were recorded on a Thermo Scientific Nicolet iS5 with an iD7 diamond ATR attachment and are uncorrected.

Surface area measurements were conducted on a Micromeritics ASAP 2020 Surface Area and Porosity Analyzer using ca. $15 \mathrm{mg}$ samples. Nitrogen isotherms were generated by incremental exposure to ultra high purity nitrogen up to ca. $1 \mathrm{~atm}$ in a liquid nitrogen $(77 \mathrm{~K})$ bath. Surface parameters were determined using BET adsorption models in the instrument software. Pore size distributions were determined using the non-local density functional theory (NLDFT) model (cylindrical pore, $\mathrm{N}_{2}$ - Cylindrical Pores - Oxide Surface) in the instrument software (Micromeritics ASAP 2020 V4.02).

${ }^{1} \mathrm{H}$ NMR spectra were recorded in deuterated solvents on either a Bruker Advance DPX 400 (400 MHz), Neo 400 (400 MHz), or AVII $400(400 \mathrm{MHz}$ ). Chemical shits are reported in parts per million (ppm, $\delta$ ) using the solvent as the internal standard.

Solid-state ${ }^{13} \mathrm{C}$ NMR spectra for COF samples were recorded using a Bruker Advance III HD $600 \mathrm{MHz}$ spectrometer with wide-bore Ascend magnet (600.27 MHz) using a $3.2 \mathrm{~mm}$ magic angle spinning (MAS) HXY solid-state NMR probe and running $20 \mathrm{k}$ scans. Cross-polarization with MAS (CP-MAS) was used to acquire ${ }^{13} \mathrm{C}$ data at $150.95 \mathrm{MHz}$. The ${ }^{13} \mathrm{C}$ cross polarization time was $2.4 \mathrm{~ms}$ at $50 \mathrm{kHz}$ with a $3 \mathrm{~s}$ relaxation delay for ${ }^{13} \mathrm{C}$. ${ }^{1} \mathrm{H}$ decoupling was applied during data acquisition. The decoupling power corresponded to $100 \mathrm{kHz}$. The HXY sample spinning rate was $15 \mathrm{kHz}$. A $20 \mathrm{~Hz}$ line broadening was applied.

ICP-AES (GLI Procedure ME-70) and Elemental analysis (GLI Procedure ME-14) was performed by Galbraith Laboratories.

ICP-MS quantitative measurements were performed on a ThermoFinnigan Element2 Inductively Coupled Plasma Sector Field Mass Spectrometer. A calibration standard was made from a $100 \mathrm{ppm}$ commercial multi-element standard (that contains $\mathrm{Ni}$ ) and diluted to $10 \mathrm{ppb}$. Using a laboratory blank of $1 \%$ nitric acid (and laboratory deionized water) and the $10 \mathrm{ppb}$ standard, a linear calibration was produced. The sample was compared to the $10 \mathrm{ppb}$ standard.

Thermogravimetric analysis (TGA) was performed on a Discovery TGA 550 using a ramp rate of 5 ${ }^{\circ} \mathrm{C} / \mathrm{min}$ from room temperature to $1000{ }^{\circ} \mathrm{C}$ under nitrogen gas.

Gas chromatographic analysis of reaction mixtures was done on the HP 5890 series II GC equipped with HP-5MS (Crosslinked 5\% PH ME Silicone) methyl phenyl silicone column (30 m, $0.32 \mathrm{~mm} \mathrm{I.D,} 0.25$ $\mu \mathrm{m})$ and hydrogen as carrier gas with FID-detector at $250{ }^{\circ} \mathrm{C}$. 
Scanning electron microscopy (SEM) was performed on a ThermoFisher Apreo Field Emission SEM. The powdered sample was deposited thinly by gently scraping material over the surface of a carbon sticky tab attached to an aluminum sample stub. The sample was imaged without any metal coating to preserve the morphology of potentially nanoscale features of interest. To mitigate image artefacts from sample charging, the SEM chamber was first pumped to high vacuum and then back-filled with $50 \mathrm{~Pa}$ of water vapor. A pressure limiting aperture was attached to the pole piece to enable use of the Apreo's in-column voltage booster tube and electrostatic final lens features. The accelerating voltage was set to $1.3 \mathrm{kV}$, and images were collected using a Low Vacuum Detector.

UV-Vis absorbance spectra were recorded on a Cary 5000 UV-Vis/NIR spectrophotometer using an internal DRA with stock powder cell holder to record the \% reflectance spectra. Solid state samples of NiDBA-2D-COF were as-synthesized and prepared in the glovebox, brought out in the sample holder and recorded quickly to minimize oxidation of the nickel in the COF.

X-ray diffraction patters were recorded on a Bruker D8 Powder X-Ray Diffractometer employing Cu $\mathrm{K}(\alpha)^{1}$ line focused irradiation at $40 \mathrm{kV}, 50 \mathrm{~mA}$ power and equipped with a Ge (111) monochromater. Samples were mounted on a zero background sample holder by dropping powders from a vial and then flattening them by firmly pressing the sample with a wide-blade spatula. No sample grinding was used prior to analysis. The holder was then placed on the mounting apparatus in the diffractometer. Data was collected after a 12 minute delay time using a $0.015^{\circ} 2 \theta$ step scan from $2-40^{\circ} 2 \theta$ with an exposure time of 2-3 sec per step.

X-Ray photoelectron spectroscopy (XPS) was performed on a Kratos Axis Ultra XPS instrument. A momochromatic aluminum X-Ray $(12 \mathrm{kV}, 10 \mathrm{~mA})$ source was used, with a charge neutralizer to minimize sample charging. The carbon 1s peak was subsequently calibrated to $284.4 \mathrm{eV}$ with sample dwells ranging from 75-100 and 8 sweeps for each element. The samples were prepared in the glovebox and transferred to the instrument without exposure to air.

\section{Synthetic Methods}

\section{Scheme S1: Synthesis of Ni-DBA[12].}

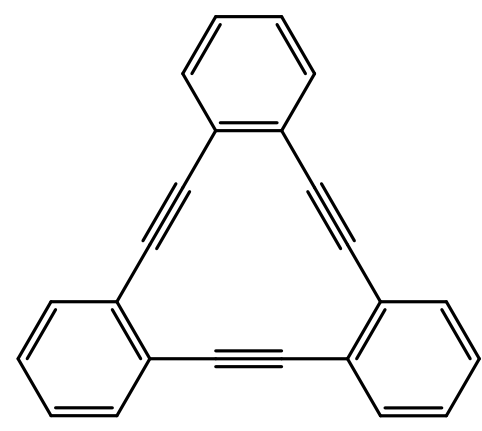

DBA[12]

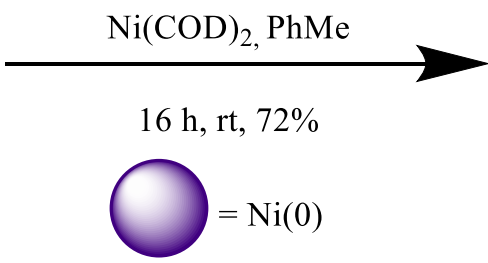

Ni-DBA[12]

DBA[12]: This compound was synthesized using procedures from McGrier and co-workers. ${ }^{1}$

Ni-DBA[12]: The following procedure was done entirely within an argon glovebox with the use of flamedried glassware as well as dry and degassed solvents. DBA[12] (162 mg, $0.54 \mathrm{mmol}), \mathrm{Ni}(\mathrm{COD})_{2}$ (148 
$\mathrm{mg}, 0.54 \mathrm{mmol})$, and toluene $(2 \mathrm{~mL})$ were combined and stirred overnight $(16 \mathrm{~h})$. The resulting suspension quickly changed from yellow to dark blue during this time. Hexanes $(2 \mathrm{~mL})$ was added to the solution and the solids were then collected by vacuum filtration, washing with hexanes $(\sim 10 \mathrm{~mL})$, yielding Ni-DBA[12] as dark blue solids (139 $\mathrm{mg}, 0.39 \mathrm{mmol} 72 \%) .{ }^{1} \mathrm{H}-\mathrm{NMR}\left(\mathrm{C}_{6} \mathrm{D}_{6}, 400 \mathrm{MHz}\right) \partial 7.58$ $(\mathrm{m}, 6 \mathrm{H}) ; 6.81(\mathrm{~m}, 6 \mathrm{H}){ }^{2}$

\section{Scheme S2: Synthesis of Ni-DBA-2D-COF.}

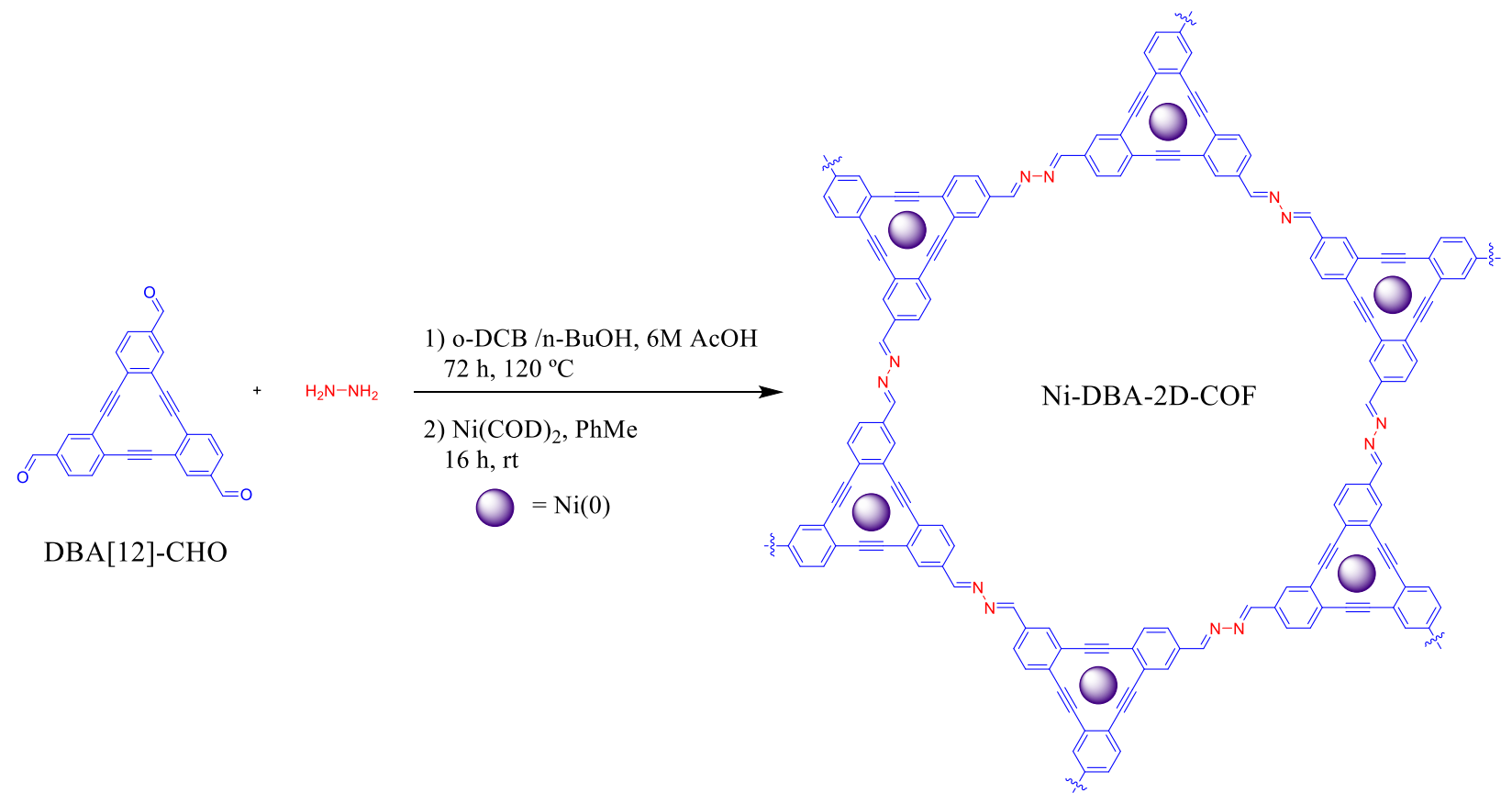

DBA[12]-CHO: This compound was synthesized using procedures from McGrier and co-workers. ${ }^{1}$

DBA-COF 5: DBA[12]-CHO (20 mg, $0.05 \mathrm{mmol})$ and hydrazine monohydrate $(4.3 \mu \mathrm{L}, 0.089 \mathrm{mmol}$, 1.77 equiv.) were combined with $o$-dichlorobenzene $(2.4 \mathrm{~mL}, 0.021 \mathrm{M})$ and $n-\mathrm{BuOH}(0.1 \mathrm{~mL}, 0.5 \mathrm{M})$ in a $10 \mathrm{~mL}$ pre-scoured ampule (Sigma-Z184985). The suspension was then sonicated for $1 \mathrm{~min}$ before the addition of $6 \mathrm{M} \mathrm{AcOH}(0.1 \mathrm{~mL}, 0.5 \mathrm{M})$. The solution was then frozen in liquid $\mathrm{N}_{2}$ and sealed under reduced pressure ( $\sim 150 \mathrm{mTorr})$, which subsequently reduced the ampule to $8.5 \mathrm{~cm}(\mathrm{~L})$. The sealed ampule was then placed in a pre-heated oven at $120{ }^{\circ} \mathrm{C}$ for $72 \mathrm{~h}$. After cooling to room temperature, the ampule was opened and the resulting COF was collected by vacuum filtration, washing with $\mathrm{MeOH}$. The COF powders were then solvent exchanged by stirring for $30 \mathrm{~min}$ in a dry round bottom flask charged with dry DMF $(3 \times 50 \mathrm{~mL})$ then dry $\mathrm{MeOH}(3 \times 50 \mathrm{~mL})$, filtering and washing with $\mathrm{MeOH}$ each time. The collected COF (18.4 mg, 97\%) was further activated on the ASAP 2020 instrument at $150{ }^{\circ} \mathrm{C}$ for $12 \mathrm{~h}$ to remove residual solvent before taking porosity measurements. FT-IR (powder, ATR) 1698, 1620, 1594, 1539, 1489, 1408, 1329, 1261, 1198, 1081, 945, 886, 820, 732, $605 \mathrm{~cm}^{-1}$. Elemental Analysis for $\left(\mathrm{C}_{27} \mathrm{H}_{12} \mathrm{~N}_{3}\right)_{n}$ : Calculated: C (85.70), H (3.20), N (11.10); Observed: C (81.77\%), H (3.20\%), N (10.37\%). ${ }^{13} \mathrm{C}$ CP-MAS NMR (150.95 MHz) $\partial$ 159.8, 132.2, 129.2, 93.3.

Ni-DBA-2D-COF: The following procedure was done entirely within an argon glovebox with the use of flame-dried glassware as well as dry and degassed solvents. DBA-COF 5 (67 mg), Ni(COD) 2 (49 mg, $0.177 \mathrm{mmol})$, and toluene $(6.5 \mathrm{~mL})$ were combined and stirred overnight $(16 \mathrm{~h})$. The resulting suspension quickly changed from yellow to dark green during this time. The Ni-DBA-2D-COF solids were then 
collected by vacuum filtration, washing with hexanes $(\sim 10 \mathrm{~mL})$. ICP-AES found $8.56 \mathrm{wt} \%$ of $\mathrm{Ni}$ in the COF. FT-IR (powder, ATF) 1694, 1620, 1593, 1539, 1489, 1409, 1328, 1198, 1081, 945, 885, 821, 730, $605 \mathrm{~cm}^{-1} .{ }^{13} \mathrm{C}$ CP-MAS NMR (150.95 MHz) d 159.9, 141.5, 132.4, 128.1, 109.7, 93.3.

\section{Synthesis of Aryl-Methylthioether Starting Materials}<smiles>COc1ccccc1SC</smiles>

2-(Methylthio)anisole (1b): $\mathrm{NaH}(139 \mathrm{mg}, 5.8 \mathrm{mmol}, 1.4$ equiv.) was added to dry THF (3 mL) and cooled to $0{ }^{\circ} \mathrm{C}$ under an inert atmosphere. A premade solution of 2-(methylthio)phenol $(0.5 \mathrm{~mL}, 4.1$ mmol, 1.0 equiv.) in dry THF ( $4 \mathrm{~mL})$ was then slowly added to the cooled solution, where it was stirred for $10 \mathrm{~min}$. MeI $\left(0.84 \mathrm{~mL}, 13.4 \mathrm{mmol}, 3.25\right.$ equiv.) was quickly added at $0{ }^{\circ} \mathrm{C}$ followed by refluxing for $19 \mathrm{~h}$. Upon cooling to room temperature, the reaction was quenched with $\mathrm{H}_{2} \mathrm{O}$, filtered through celite, and extracted with hexanes to give the title compound as a pale-yellow oil in quantitative yield. ${ }^{1} \mathrm{H}-\mathrm{NMR}$ $\left(\mathrm{CDCl}_{3}, 400 \mathrm{MHz}\right)$ 2 7.18-7.12 (m, 2H); $6.96(\mathrm{dt}, 1 \mathrm{H}) ; 6.84(\mathrm{dd}, 1 \mathrm{H}) ; 3.90(\mathrm{~s}, 3 \mathrm{H}) ; 2.44(\mathrm{~s}, 3 \mathrm{H}){ }^{3}$<smiles>COC(=O)c1ccc(SC)cc1</smiles>

Methyl 4-(methylthio)benzoate (1d): This compound was synthesized using procedures from Hosoya and co-workers. ${ }^{4}$<smiles>CSc1ccc(-c2ccc(SC)cc2)cc1</smiles>

4,4'-Bis(methylthio)-1,1'-biphenyl (1g): 4-Bromothioanisole (300 mg, $1.48 \mathrm{mmol}, 1.0$ equiv.), 4(methylthio)phenylboronic acid (496 mg, $2.95 \mathrm{mmol}, 2.0$ equiv.), $\mathrm{K}_{2} \mathrm{CO}_{3}$ (408 mg, $2.95 \mathrm{mmol}, 2.0$ equiv.), and $\mathrm{Pd}\left(\mathrm{PPh}_{3}\right)_{4}(86 \mathrm{mg}, 0.074 \mathrm{mmol}, 0.05$ equiv.) were combined in an argon filled glovebox. In a separate flask, $\mathrm{H}_{2} \mathrm{O}(3 \mathrm{~mL})$ and toluene $(15 \mathrm{~mL})$ were combined and degassed via free-pump-thaw method, backfilling with $\mathrm{N}_{2}$. The degassed solvent was then transferred to the flask containing the solids under $\mathrm{N}_{2}$. The solution was then heated to reflux for $24 \mathrm{~h}$. After cooling to room temperature, the organics were extracted with DCM, then purified on a silica gel column $(0 \rightarrow 30 \%$ DCM in hexanes $)$ to yield the pure product as a white solid $(242 \mathrm{mg}, 0.982 \mathrm{mmol}, 66 \%) .{ }^{1} \mathrm{H}-\mathrm{NMR}\left(\mathrm{CDCl}_{3}, 400 \mathrm{MHz}\right)$ o $7.50(\mathrm{~d}, 4 \mathrm{H})$; $7.32(\mathrm{~d}, 4 \mathrm{H}) ; 2.52(\mathrm{~s}, 6 \mathrm{H}) .^{5}$ 


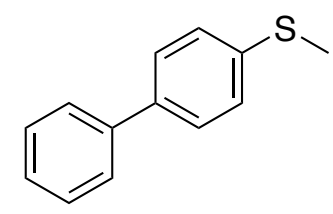

4-(Methylthio)-1,1'-biphenyl (1h): This compound was synthesized using procedures from Watson and co-workers. ${ }^{6}$

\section{FT-IR Spectra}

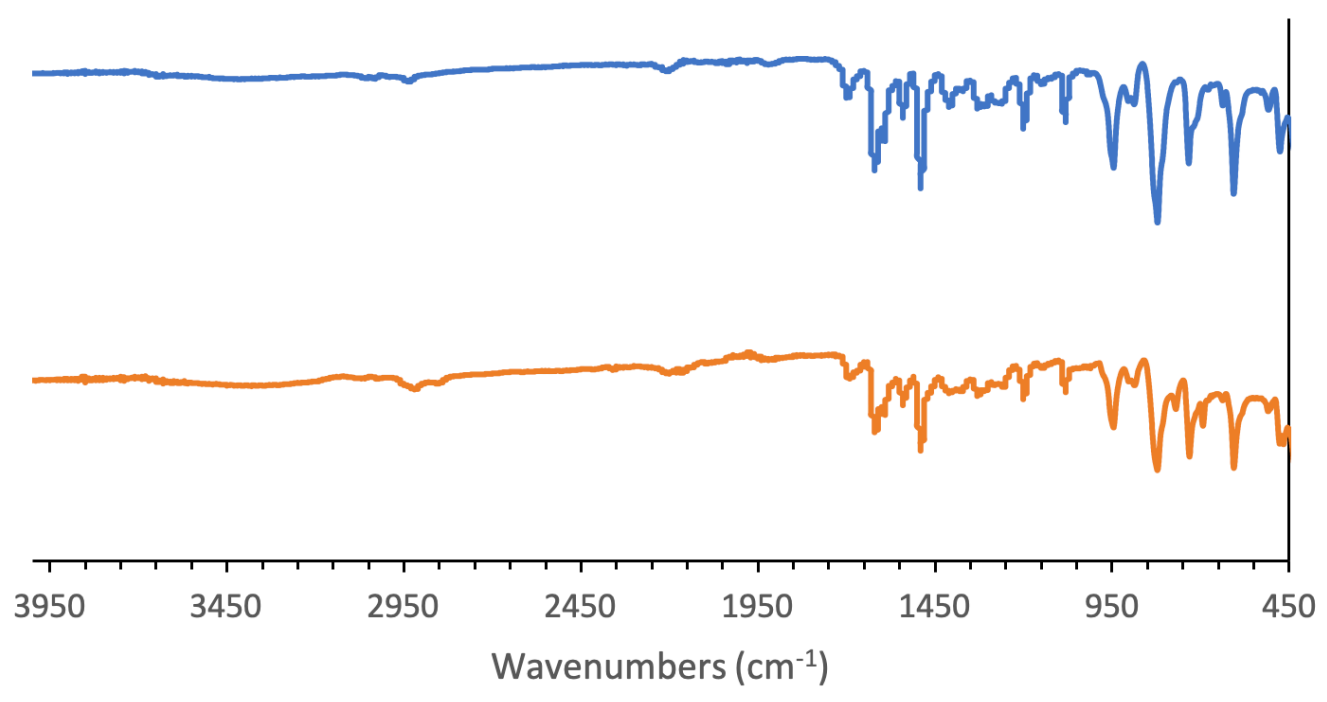

Figure S1: FT-IR comparison of DBA-COF 5 (blue) to Ni-DBA-2D-COF (orange).

\begin{tabular}{|c|c|c|}
\hline Functional Group & DBA-COF 5 Frequency $\left(\mathrm{cm}^{-1}\right)$ & Ni-DBA-2D-COF Frequency $\left(\mathrm{cm}^{-1}\right)$ \\
\hline $\mathrm{C} \equiv \mathrm{C}$ & 2207 & 2200 \\
\hline $\mathrm{C}=\mathrm{N}$ & 1620 & 1620 \\
\hline $\mathrm{N}-\mathrm{N}$ & 1081 & 1081 \\
\hline
\end{tabular}

Table S1: FT-IR frequencies of key functional groups in DBA-COF 5 and Ni-DBA-2D-COF.

\section{E. Experimental \& Simulated PXRD Patterns}

The simulated PXRD profiles were performed using Materials Studio 2018 using the unit cell precursor shown in Figure S2. Before the simulations were performed the precursor was optimized using the geometry optimization task and Universal Forcefield parameters from the Forcite module. DBA-COF 5 was then modeled using a primitive hexagonal unit cell with a $P 6$ space group in which the stacking layers were offset by $9 \AA$. The $\mathrm{a}=\mathrm{b}$ parameters were estimated by measuring the distance between the imine-linked phenyl ring of the COF. The c parameter was arbitrarily set at $3.4 \AA$. Simulation of the possible structure was performed using the Reflux Plus module to produce the expected PXRD profile. The experimental PXRDs were then subjected to a Pawley refinement using Pseudo-Voigt peak shape function and Berar-Baldinozzi asymmetry correction function to produce the refined PXRD profile. 


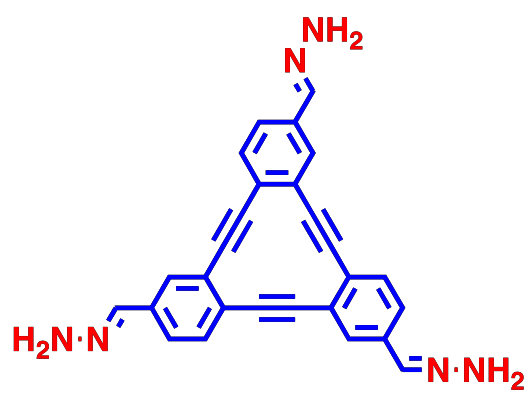

Figure S2: Precursor used to construct the hexagonal unit cell for DBA-COF 5.

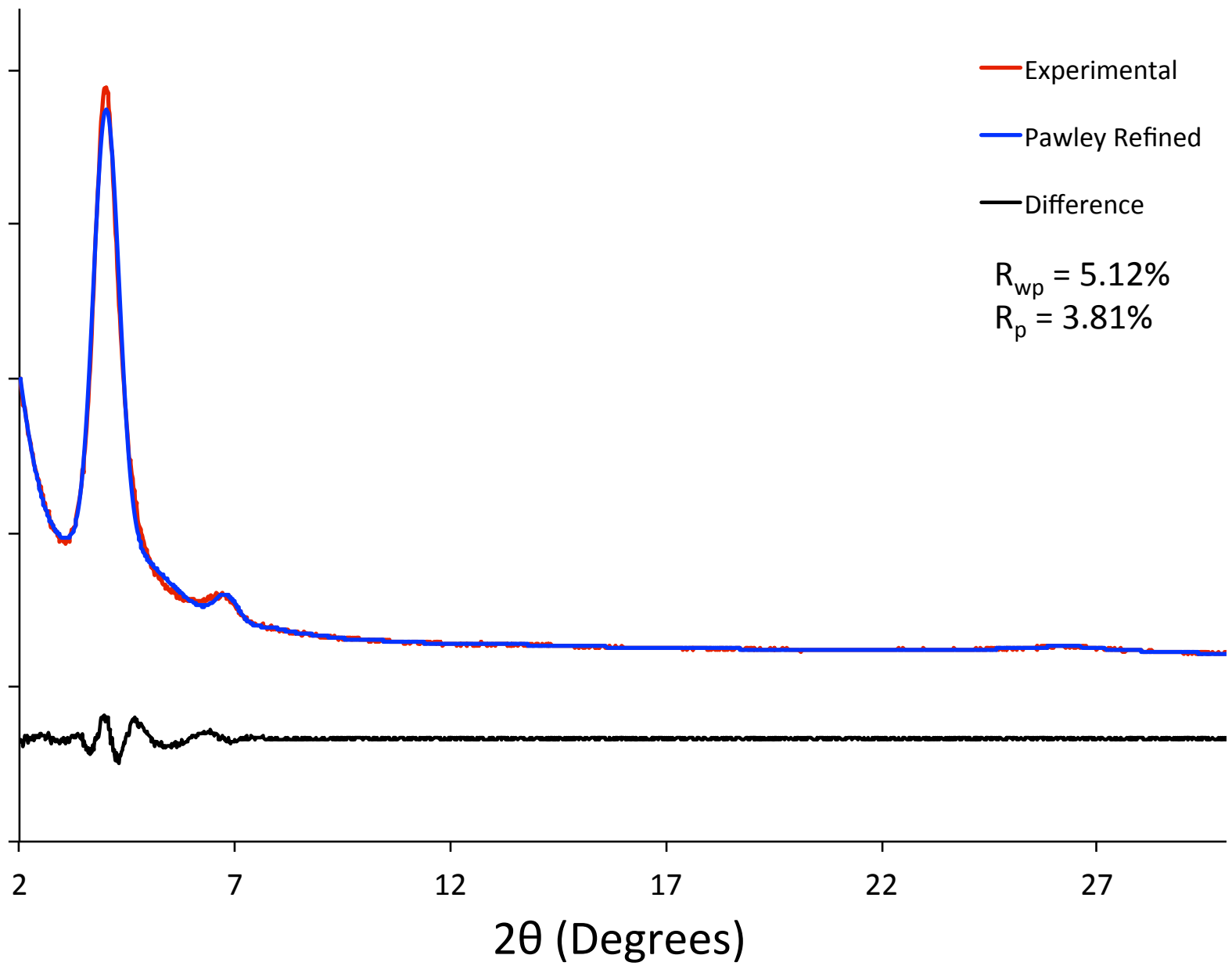

Figure S3: Experimental (red), Pawley refined (blue), and difference plot (black) PXRD patterns of DBA-COF 5. 


\begin{tabular}{|cccc|}
\hline \multicolumn{5}{|c|}{ DBA-COF 5 } \\
\hline \multicolumn{4}{|c|}{ Hexagonal, $P 6$ space group } \\
\hline Atom $=26.222, \mathrm{c}=3.4$ \\
C1 & 1.44710 & 1.51443 & 0.04173 \\
N2 & 1.49427 & 1.51793 & 0.04167 \\
N3 & 1.49808 & 1.47073 & 0.04168 \\
C4 & 1.54524 & 1.47423 & 0.04162 \\
C5 & 1.55074 & 1.42556 & 0.04164 \\
C6 & 1.60275 & 1.43174 & 0.04158 \\
C7 & 1.60943 & 1.38617 & 0.04160 \\
C8 & 1.66371 & 1.39420 & 0.04154 \\
C9 & 1.70865 & 1.39971 & 0.04149 \\
C10 & 1.76178 & 1.40486 & 0.04143 \\
C11 & 1.80768 & 1.45685 & 0.04136 \\
C12 & 1.85973 & 1.46319 & 0.04130 \\
C13 & 1.86631 & 1.41745 & 0.04132 \\
C14 & 1.92048 & 1.42294 & 0.04127 \\
N15 & 1.96416 & 1.47009 & 0.04119 \\
& & & \\
\hline
\end{tabular}

Table S2: Fractional atomic coordinates for the hexagonal unit cell of DBA-COF 5 calculated using Materials Studio 2018.

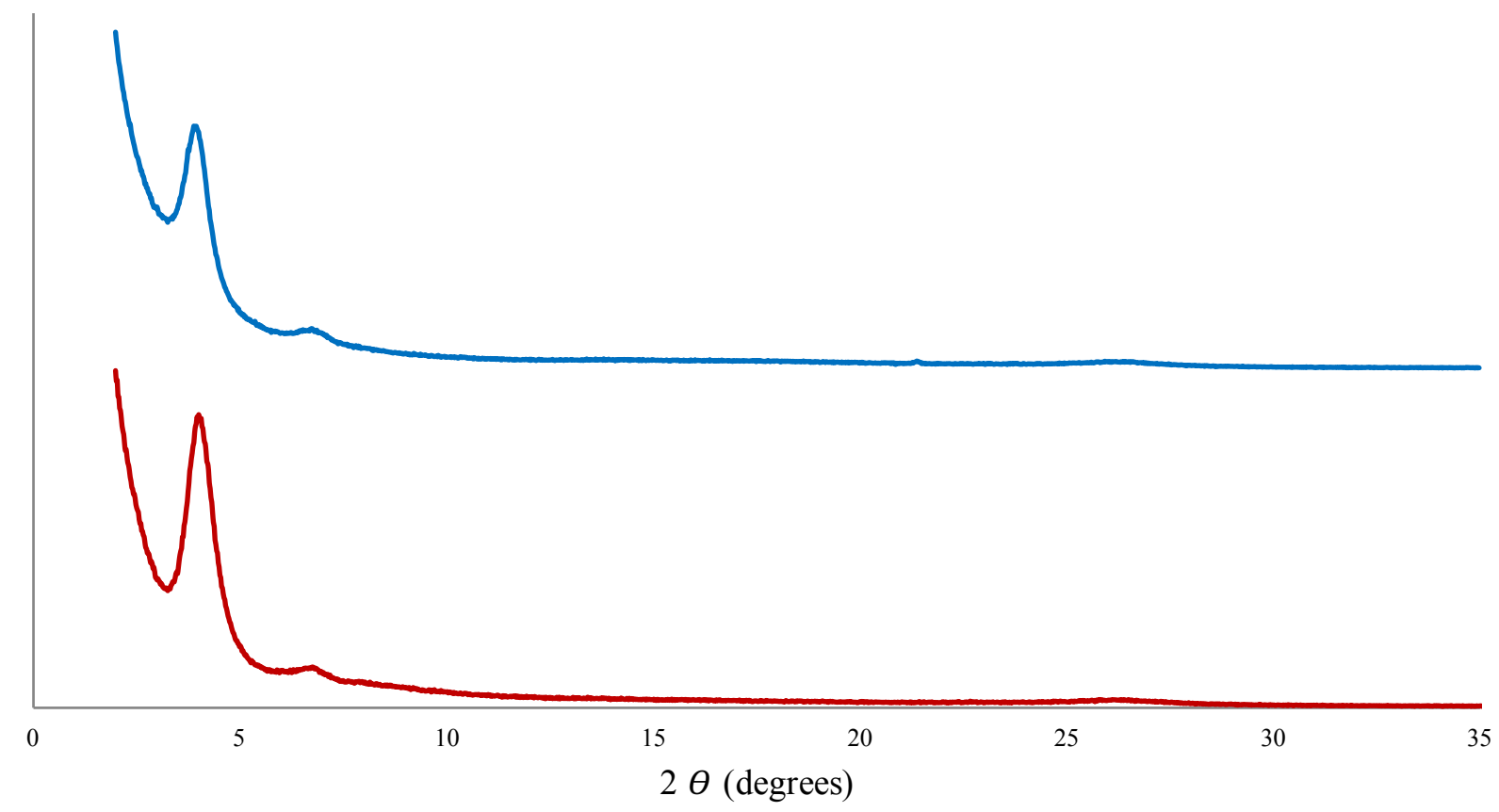

Figure S4: Overlaid PXRDs of Ni-DBA-2D-COF (blue) and DBA-COF 5 (red). 


\section{F. COF Stability Studies}

Stability Studies: Activated DBA-COF 5 (ca. $10 \mathrm{mg}$ ) was added to a screw cap vial, followed by solvent (ca. $2 \mathrm{~mL}$ ). The vial was sealed, and the mixture let soak for $24 \mathrm{~h}$ at room temperature before collecting the solids by vacuum filtration, washing with $\mathrm{MeOH}$. The obtained $\mathrm{COF}$ powders were dried in vacuo prior to obtaining PXRDs.

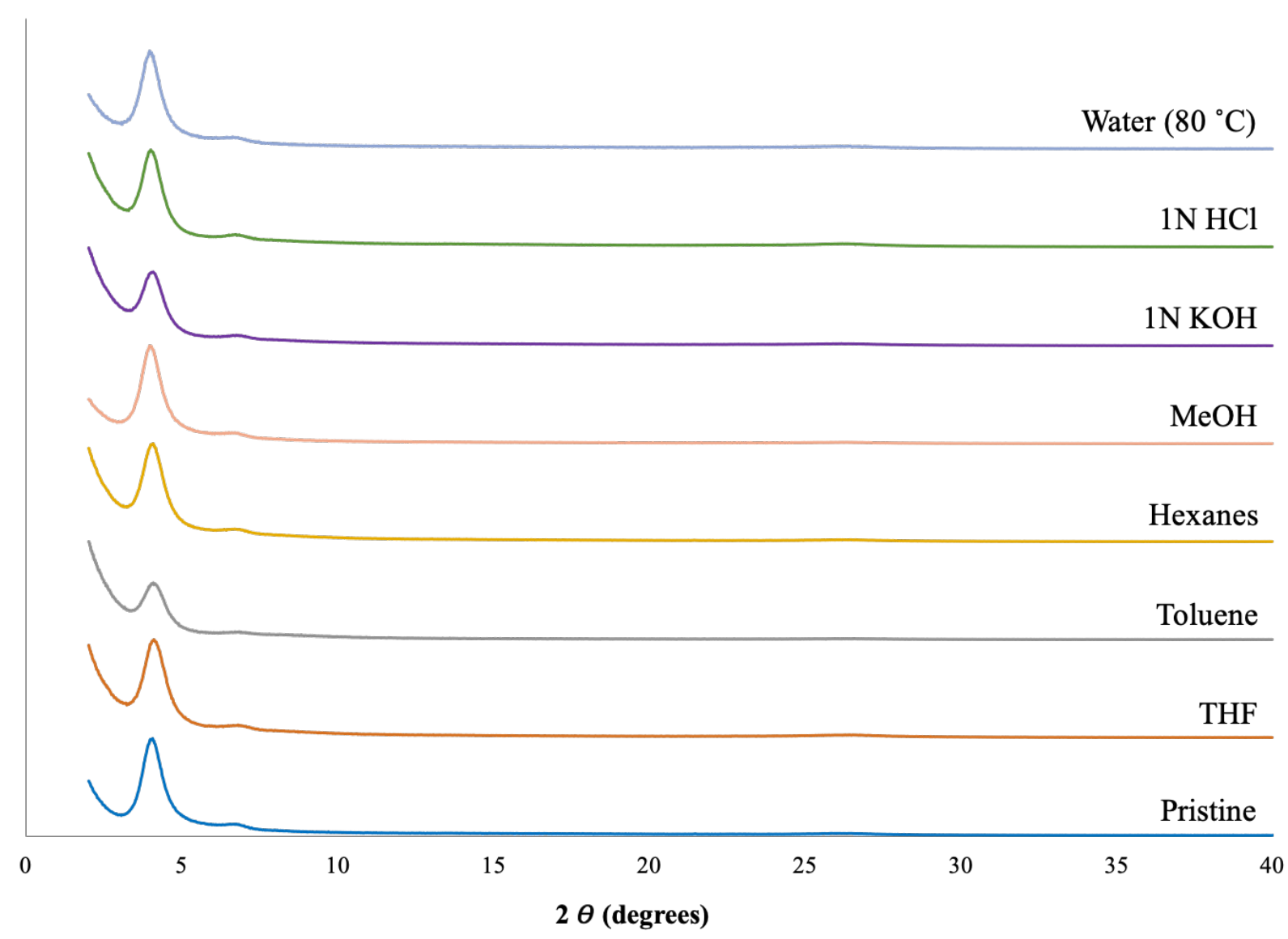

Figure S5: Overlaid PXRDs of DBA-COF 5 after soaking in various solvents for $24 \mathrm{~h}$. 


\section{G. Solid-State NMR Spectra}

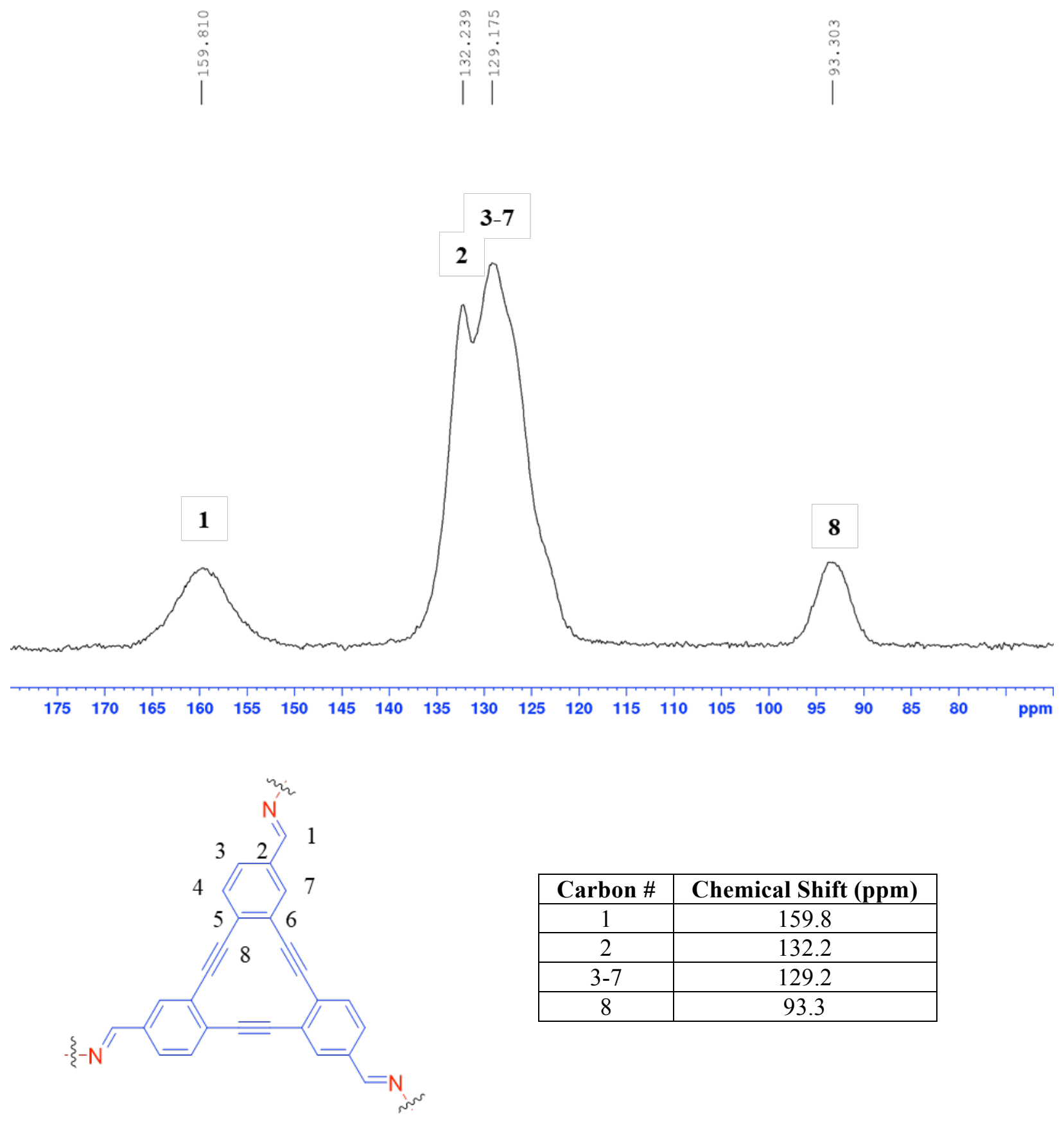

Figure S6: ${ }^{13} \mathrm{C}$ CP-MAS NMR spectrum and peak assignments of DBA-COF 5. 


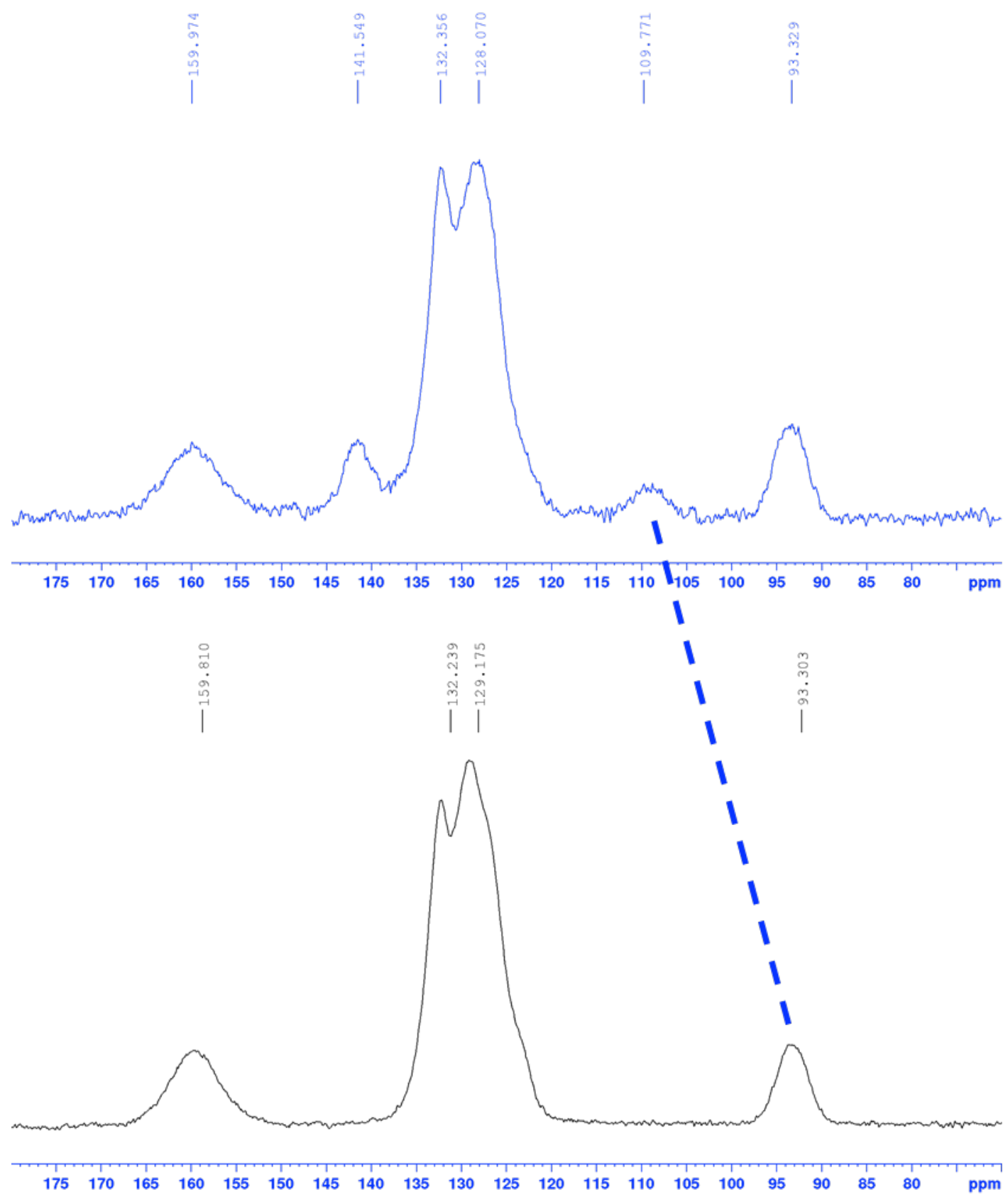

Figure S7: ${ }^{13} \mathrm{C}$ CP-MAS NMR spectrum of DBA-COF 5 (bottom) overlaid with Ni-DBA-2D-COF (top) showing the appearance of a new downfield shifted peak for the metalated alkynyl units as well as the retention of the alkynyl peak for the non-metalated DBA units. ICP-AES showed $8.56 \mathrm{wt} \% \mathrm{Ni}$, corresponding to $63.7 \%$ of DBA units being metalated. 


\section{H. BET Surface Area Plots}

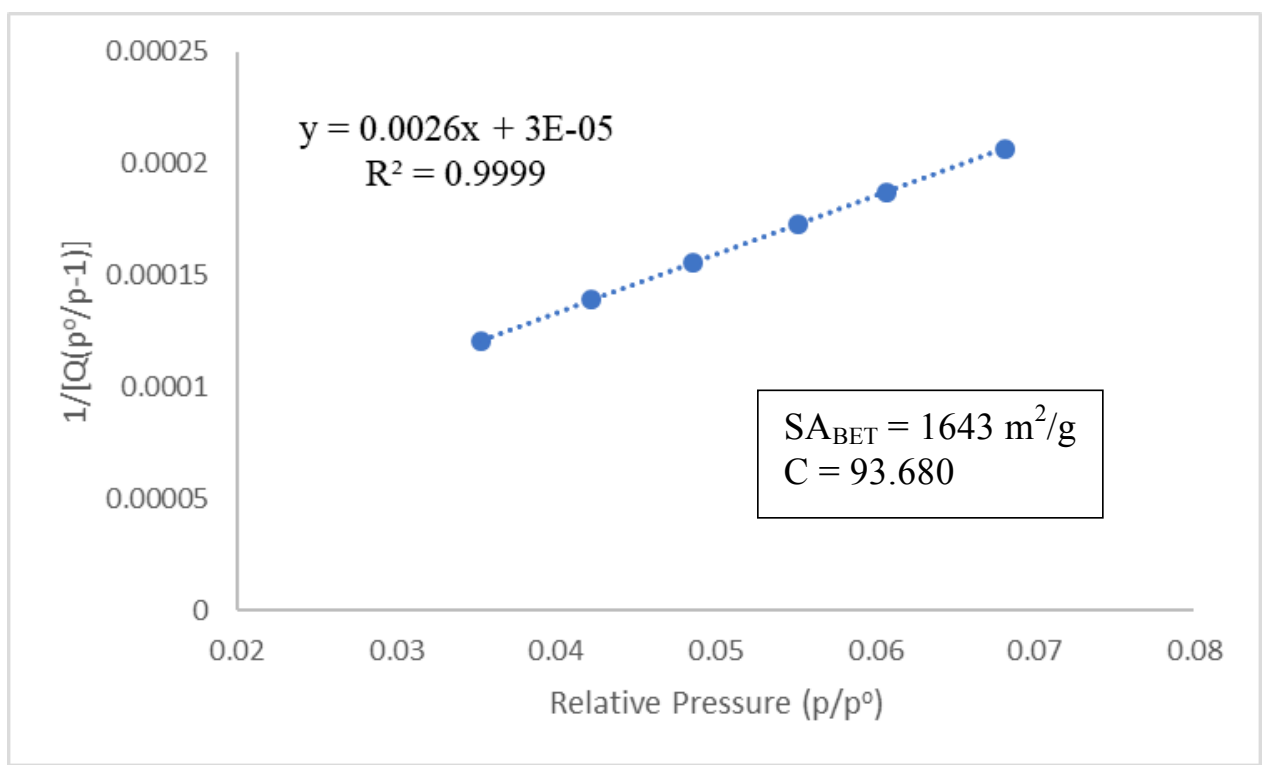

Figure S8: Linear surface area plot for DBA-COF 5.

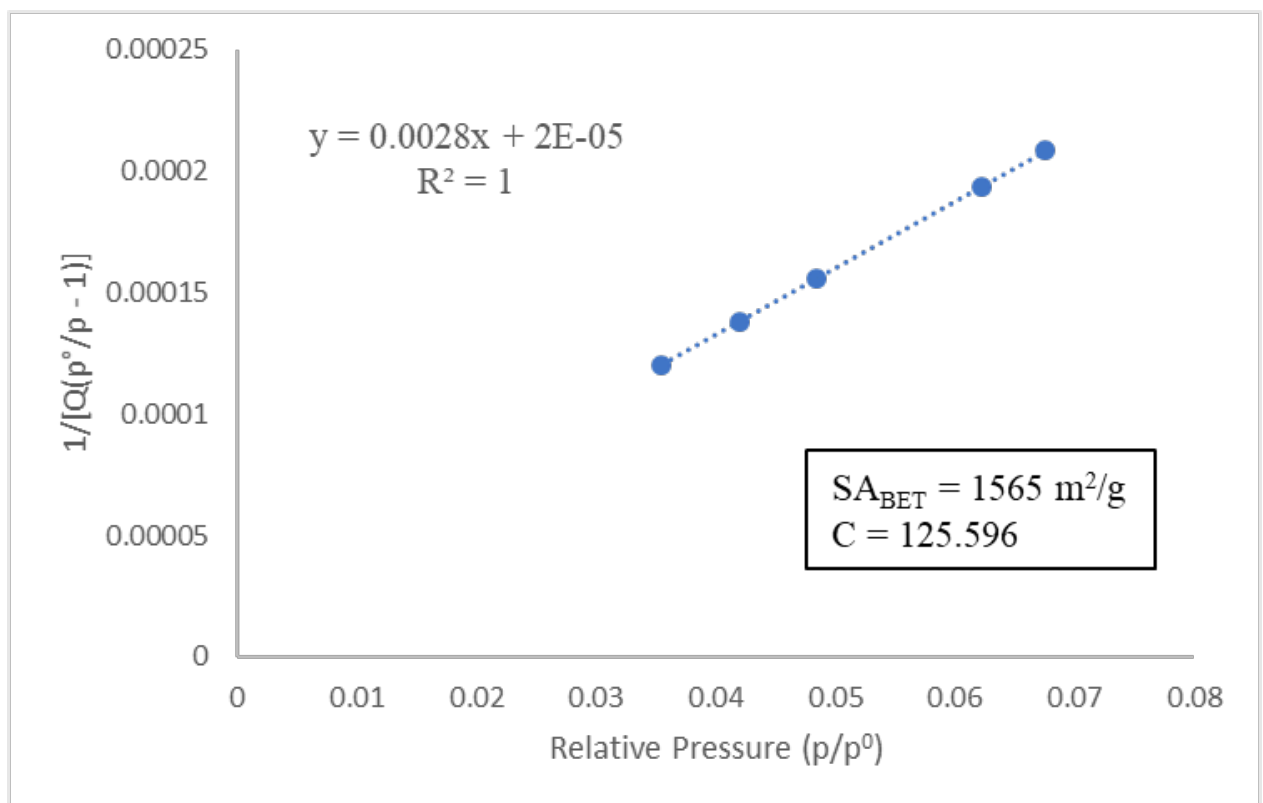

Figure S9: Linear surface area plot for Ni-DBA-2D-COF. 


\section{TGA Profile}

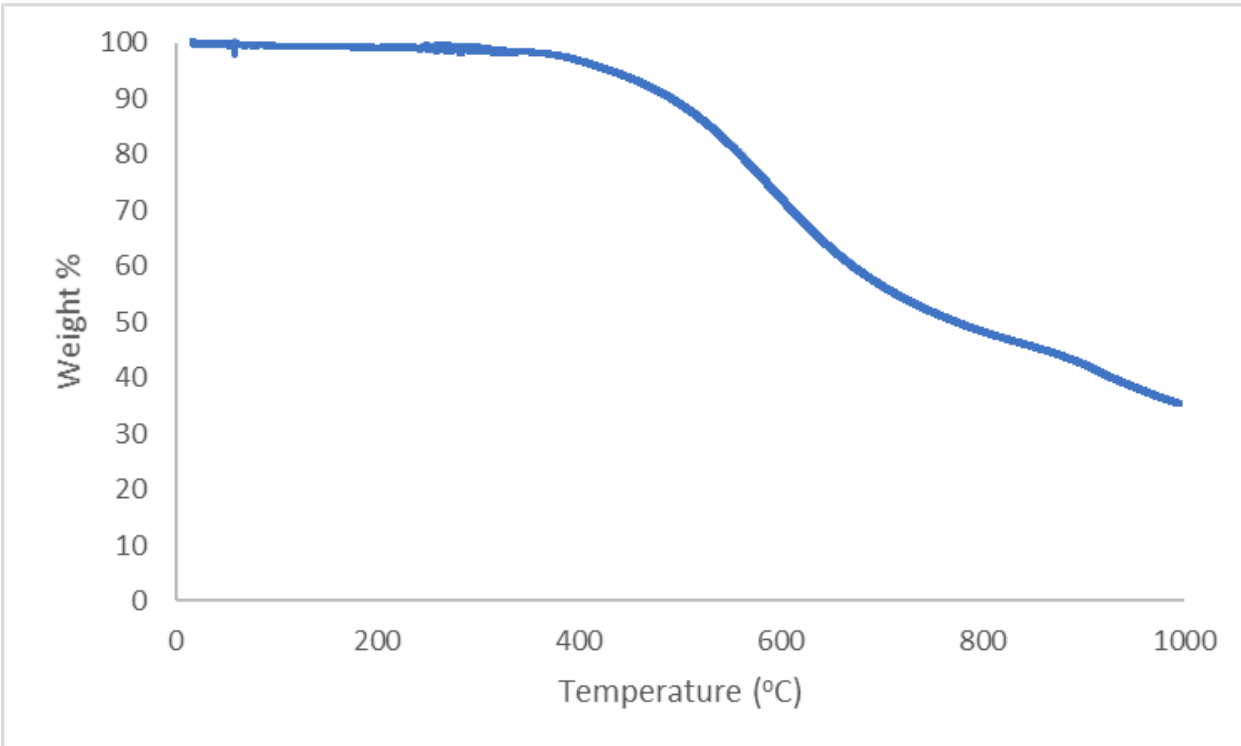

Figure S10: TGA profile for DBA-COF 5. 


\section{J. SEM Micrographs}
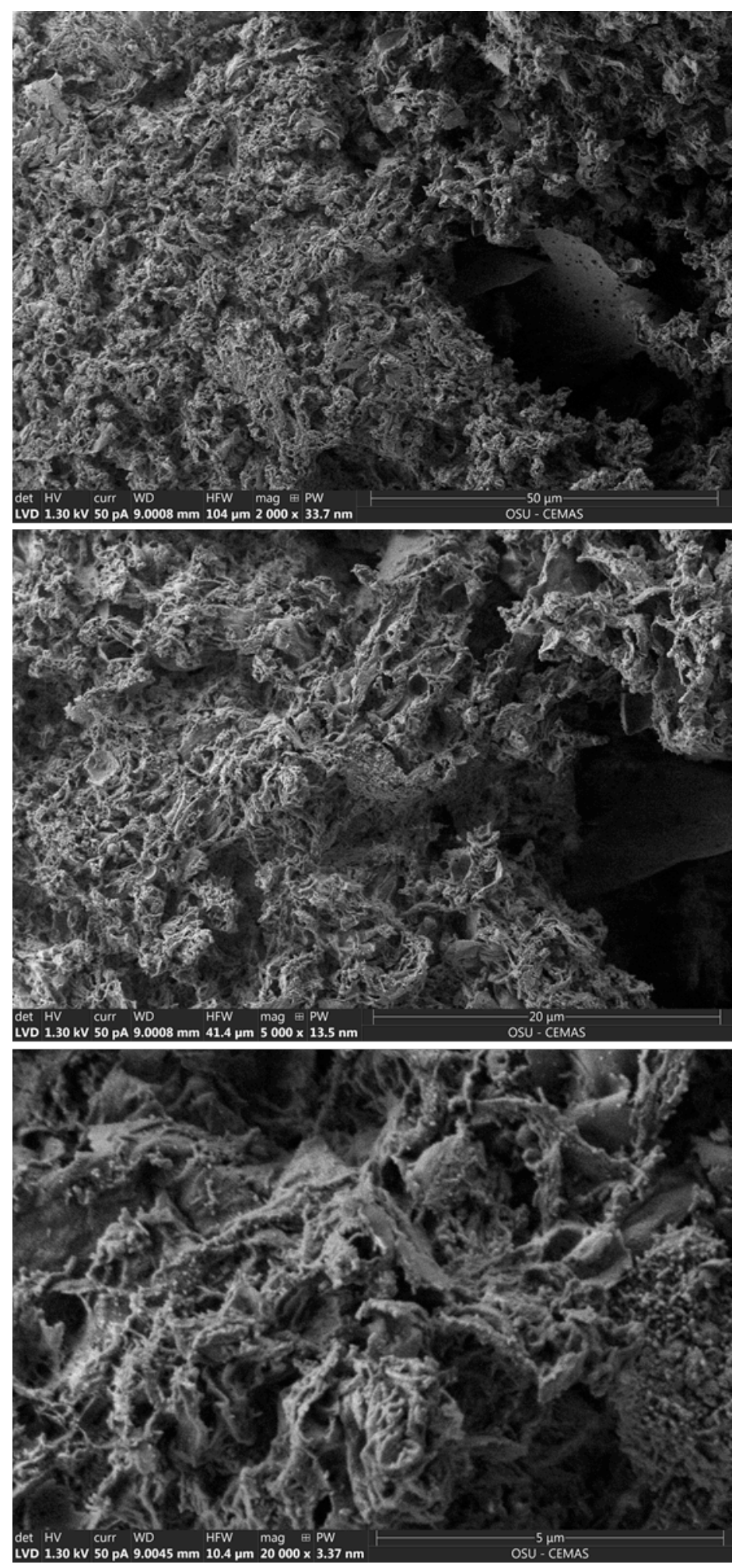

Figure S11: Scanning electron microscopy (SEM) images of DBA-COF 5 at various magnifications. 


\section{K. XPS Spectra}

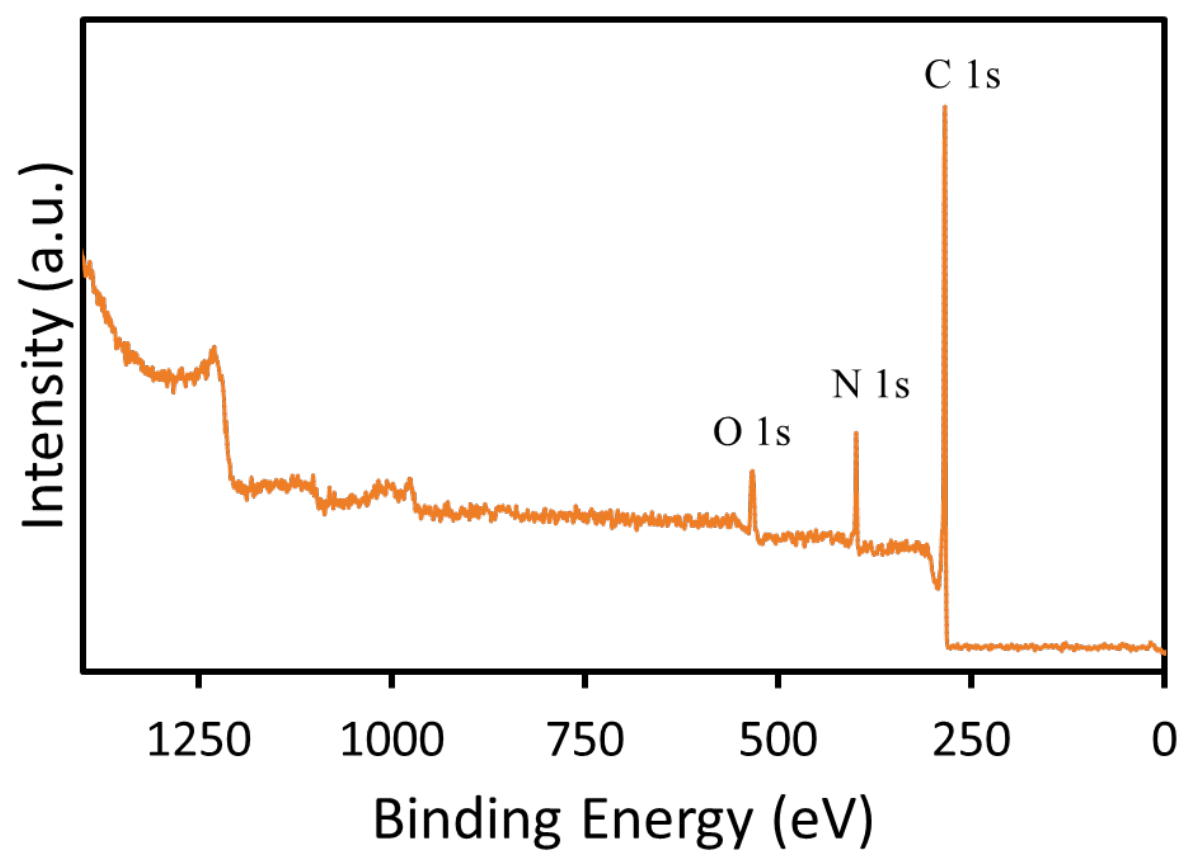

Figure S12: XPS survey of DBA-COF 5.

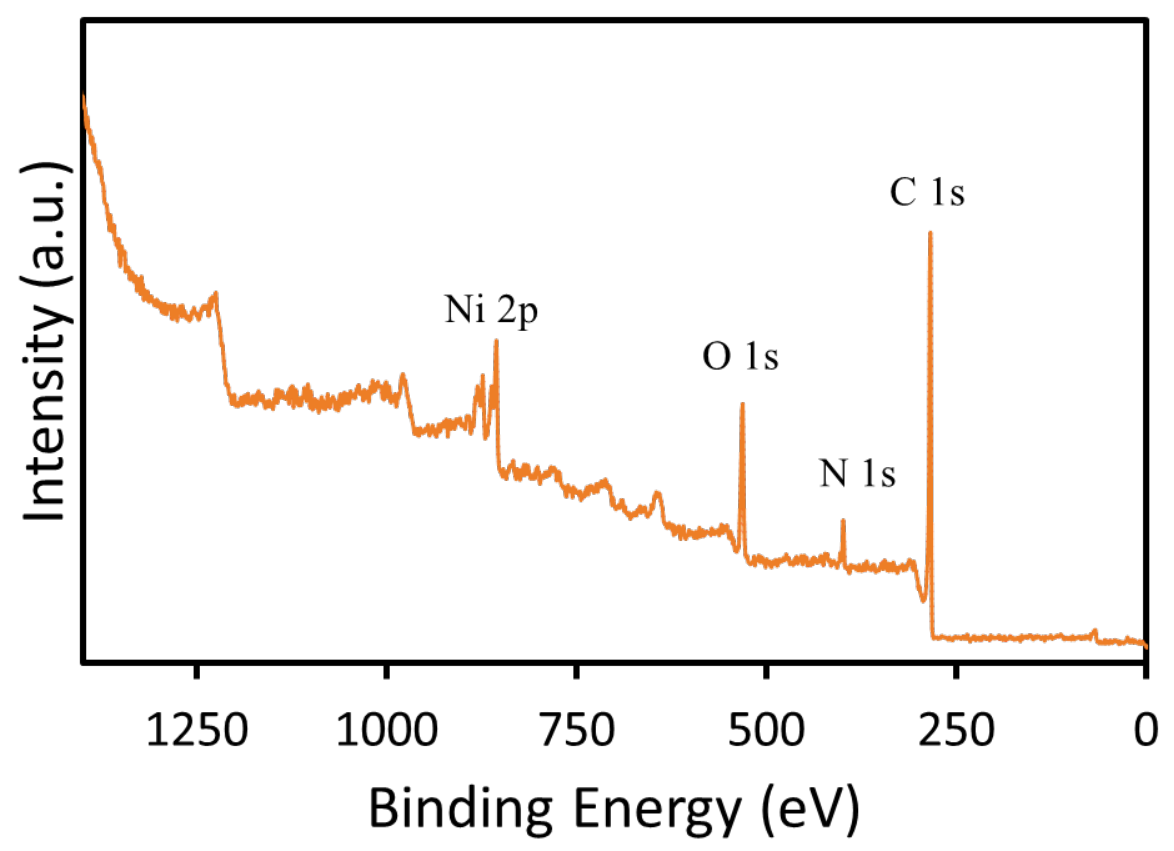

Figure S13: XPS survey of pristine Ni-DBA-2D-COF. 


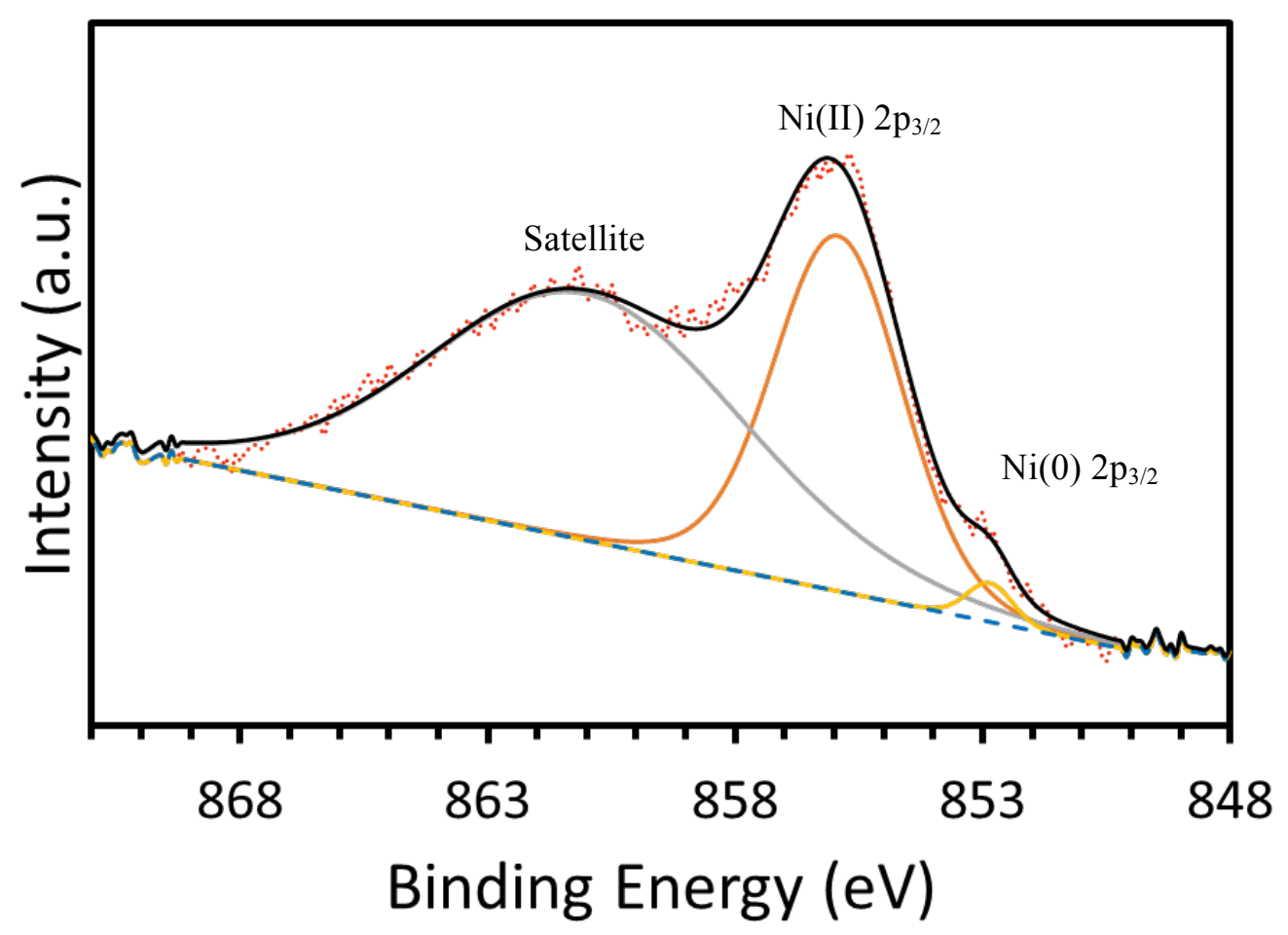

Figure S14: XPS for the Ni $2 \mathrm{p}_{3 / 2}$ region of pristine Ni-DBA-2D-COF.

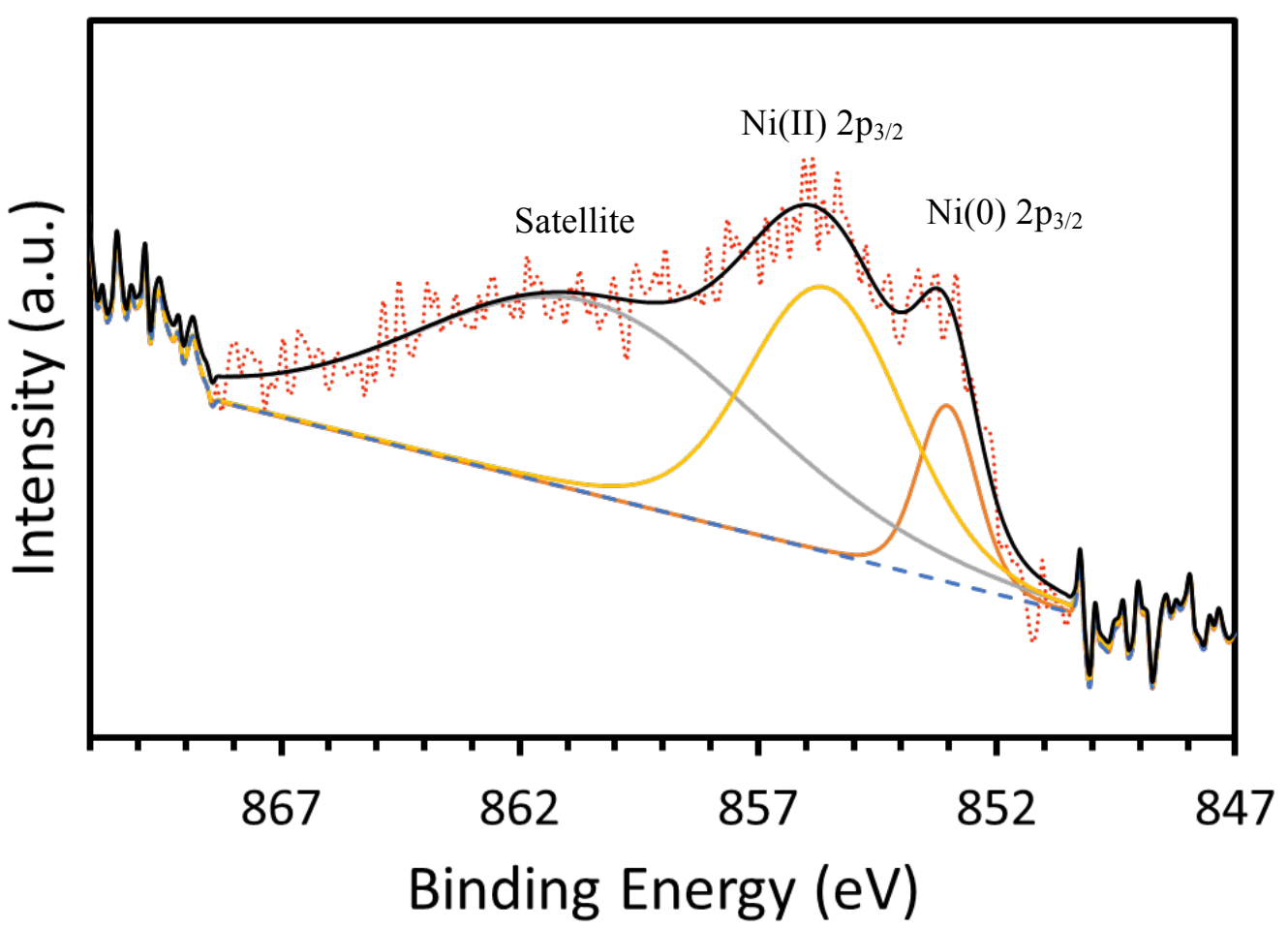

Figure S15: XPS for the Ni $2 \mathrm{p}_{3 / 2}$ region of Ni-DBA-2D-COF sample after catalysis. 


\section{Ni-Catalyzed Reductive Cleavage of Aryl Methyl Thioethers}

The yields for the Ni-DBA-2D-COF catalyzed hydrodesulfurization listed in Table 1 refer to GC-FID yields and represent an average of three independent trials. The procedures listed below are representative.

General procedure for the Ni-catalyzed reductive cleavage of aryl methyl thioethers (Table 1): To an oven dried pressure tube in an argon glovebox was added the aryl methyl thioether $(0.11 \mathrm{mmol}, 1.0$ equiv.), the Ni-catalyst (10 mol\% for Ni-DBA[12]; $5.0 \mathrm{mg}$ for Ni-DBA-2D-COF corresponding to 6 mol\% based off of ICP-AES Ni-loading content), $\mathrm{EtMe}_{2} \mathrm{SiH}$ ( $73 \mu \mathrm{L}, 5.0$ equiv.), and toluene (2.0 mL). The pressure tube was sealed and brought out of the glovebox where it was placed in a pre-heated oil bath at $130{ }^{\circ} \mathrm{C}$, where it was stirred for $14 \mathrm{~h}$. Upon cooling to room temperature, the pressure tube was opened, and the internal standard was added followed by EtOAc $(1.0 \mathrm{~mL})$. The tube was recapped, and the solution let stir for serval minutes to ensure a homogeneous mixture. An aliquot $(1.5 \mathrm{~mL})$ was then filtered through a pipet of silica, washing with EtOAc $(1.5 \mathrm{~mL})$. The filtered solution was then further filtered through a nylon membrane disc filter prior to obtaining yields by GC-FID.

\section{GC-FID experimental methods:}

[35-RAMP-B]: Initial temperature of $35{ }^{\circ} \mathrm{C}$ for a hold time of $10 \mathrm{~min}$, followed by ramping at $20{ }^{\circ} \mathrm{C} / \mathrm{min}$ until a final temperature of $250{ }^{\circ} \mathrm{C}$ was reached and held for an additional $5 \mathrm{~min}$.

[60-RAMP]: Initial temperature of $60{ }^{\circ} \mathrm{C}$ for a hold time of $5 \mathrm{~min}$, followed by ramping at $20{ }^{\circ} \mathrm{C} / \mathrm{min}$ until a final temperature of $250{ }^{\circ} \mathrm{C}$ was reached and held for an additional $15 \mathrm{~min}$.

[80-RAMP]: Initial temperature of $80{ }^{\circ} \mathrm{C}$ for a hold time of $5 \mathrm{~min}$, followed by ramping at $20{ }^{\circ} \mathrm{C} / \mathrm{min}$ until a final temperature of $250{ }^{\circ} \mathrm{C}$ was reached and held for an additional $10 \mathrm{~min}$.

[100-RAMP]: Initial temperature of $100{ }^{\circ} \mathrm{C}$ for a hold time of $3 \mathrm{~min}$, followed by ramping at $20{ }^{\circ} \mathrm{C} / \mathrm{min}$ until a final temperature of $250{ }^{\circ} \mathrm{C}$ was reached and held for an additional $5 \mathrm{~min}$.<smiles>Brc1ccccc1</smiles>

Bromobenzene (2a): Following the general procedure, 4-bromothioanisole $(22.3 \mathrm{mg})$ was used at $90{ }^{\circ} \mathrm{C}$ with veratrole $(28 \mu \mathrm{L})$ as the internal standard. Used GC-FID method [80-RAMP] to determine yields (26\% for Ni-DBA[12]; $22 \%$ for Ni-DBA-2D-COF).<smiles>COc1ccccc1</smiles>

Anisole (2b): Following the general procedure, 2-methylthioanisole (16 $\mu \mathrm{L})$ was used with veratrole (28 $\mu \mathrm{L})$ as the internal standard. Used GC-FID method [80-RAMP] to determine yields (45\% for $\mathrm{Ni}$ DBA[12]; 76\% for Ni-DBA-2D-COF). 


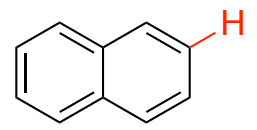

Naphthalene (2c): Following the general procedure, 2-(methylthio)naphthalene (19.9 mg) was used with anisole $(54 \mu \mathrm{L})$ as the internal standard. Used GC-FID method [100-RAMP] to determine yields (99\% for Ni-DBA[12]; 87\% for Ni-DBA-2D-COF).<smiles>COC(=O)c1ccccc1</smiles>

Methyl benzoate (2d): Following the general procedure, methyl 4-(methylthio)benzoate (20.1 mg) was used at $90{ }^{\circ} \mathrm{C}$ with anisole $(20 \mu \mathrm{L})$ as the internal standard. Used GC-FID method [80-RAMP] to determine yields (38\% for Ni-DBA[12]; 45\% for Ni-DBA-2D-COF).<smiles>Clc1ccccc1</smiles>

Chlorobenzene (2e): Following the general procedure, 4-chlorothioanisole (14 $\mu \mathrm{L})$ was used with veratrole $(127 \mu \mathrm{L})$ as the internal standard. Used GC-FID method [60-RAMP] to determine yields (79\% for Ni-DBA[12]; 46\% for Ni-DBA-2D-COF).<smiles>Fc1ccccc1</smiles>

Fluorobenzene (2f): Following the general procedure, 4-fluorothioanisole (14 $\mu \mathrm{L})$ was used with chlorobenzene $(101 \mu \mathrm{L})$ as the internal standard. Used GC-FID method [35-RAMP-B] to determine yields (72\% for Ni-DBA[12]; 44\% for Ni-DBA-2D-COF).<smiles>c1ccc(-c2ccccc2)cc1</smiles>

Biphenyl (2g): The dicleavage was achieved following the general procedure, with 4,4'-Bis(methylthio)1,1'-biphenyl (13.6 mg, $0.055 \mathrm{mmol}$ ), Ni-catalyst (20 mol\%, $0.011 \mathrm{mmol}$ for Ni-DBA; $5.0 \mathrm{mg}$ for NiDBA-2D-COF), and $\mathrm{EtMe}_{2} \mathrm{SiH}(73 \mu \mathrm{L}, 10$ equiv.), with anisole $(24 \mu \mathrm{L})$ as the internal standard. Used GC-FID method [100-RAMP] to determine yields (5\% for Ni-DBA[12]; 2\% for Ni-DBA-2D-COF). 


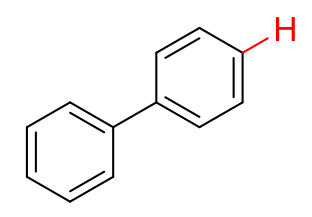

Biphenyl (2h): The monocleavage was achieved following the general procedure, 4-(Methylthio)-1,1'biphenyl $(22 \mathrm{mg})$ was used with anisole $(24 \mu \mathrm{L})$ as the internal standard. Used GC-FID method [100RAMP] to determine yields (9\% for Ni-DBA[12]; 18\% for Ni-DBA-2D-COF).

\section{Recyclability of Ni-DBA-2D-COF}

Procedure for the recyclability of Ni-DBA-2D-COF (Figure 4): To an oven dried pressure tube in an argon glovebox was added 2-(methylthio)naphthalene (79.7 mg, $0.46 \mathrm{mmol}, 1.0$ equiv.), Ni-DBA-2D$\mathrm{COF}(20 \mathrm{mg}), \mathrm{EtMe}_{2} \mathrm{SiH}(302 \mu \mathrm{L}, 5.0$ equiv.), and toluene $(8.0 \mathrm{~mL})$. The pressure tube was sealed and brought out of the glovebox where it was placed in a pre-heated oil bath at $130{ }^{\circ} \mathrm{C}$, where it was stirred for $14 \mathrm{~h}$. Upon cooling to room temperature, the pressure tube was brought into an argon filled glovebox where it was opened and the Ni-DBA-2D-COF was collected by filtration, washing with hexanes. The collected Ni-DBA-2D-COF was stored in the glovebox and used in the subsequent recyclability trial without any other purification. The filtrate was taken out of the glovebox where anisole $(54 \mu \mathrm{L})$ was added as the internal standard. An aliquot $(1.5 \mathrm{~mL})$ was then filtered through a pipet of silica, washing with EtOAc $(1.5 \mathrm{~mL})$. The filtered solution was then further filtered through a nylon membrane disc filter prior to obtaining yields by GC-FID using method [100-RAMP].

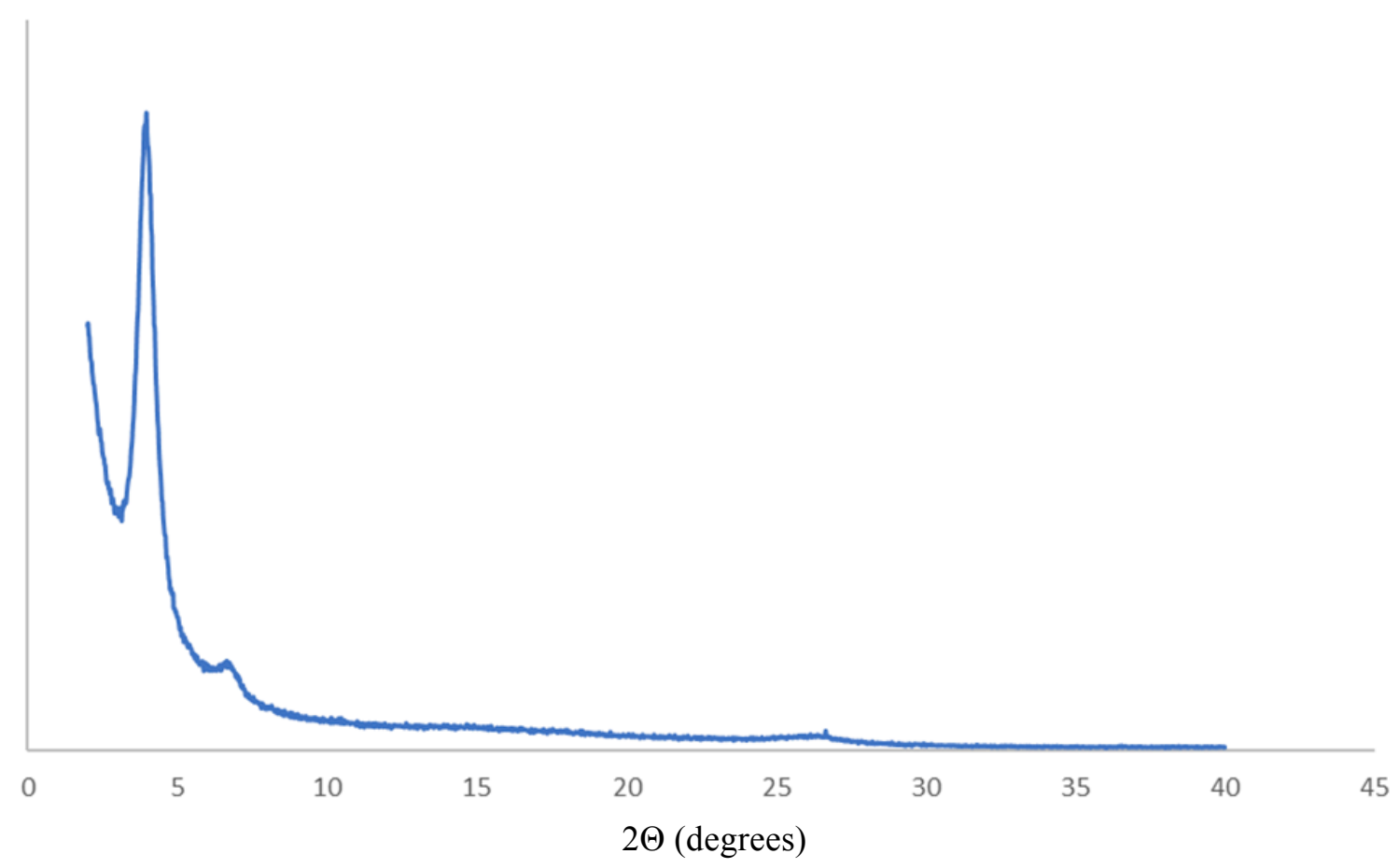

Figure S16: PXRD of Ni-DBA-2D-COF after its use for catalytic hydrodesulfurization. 


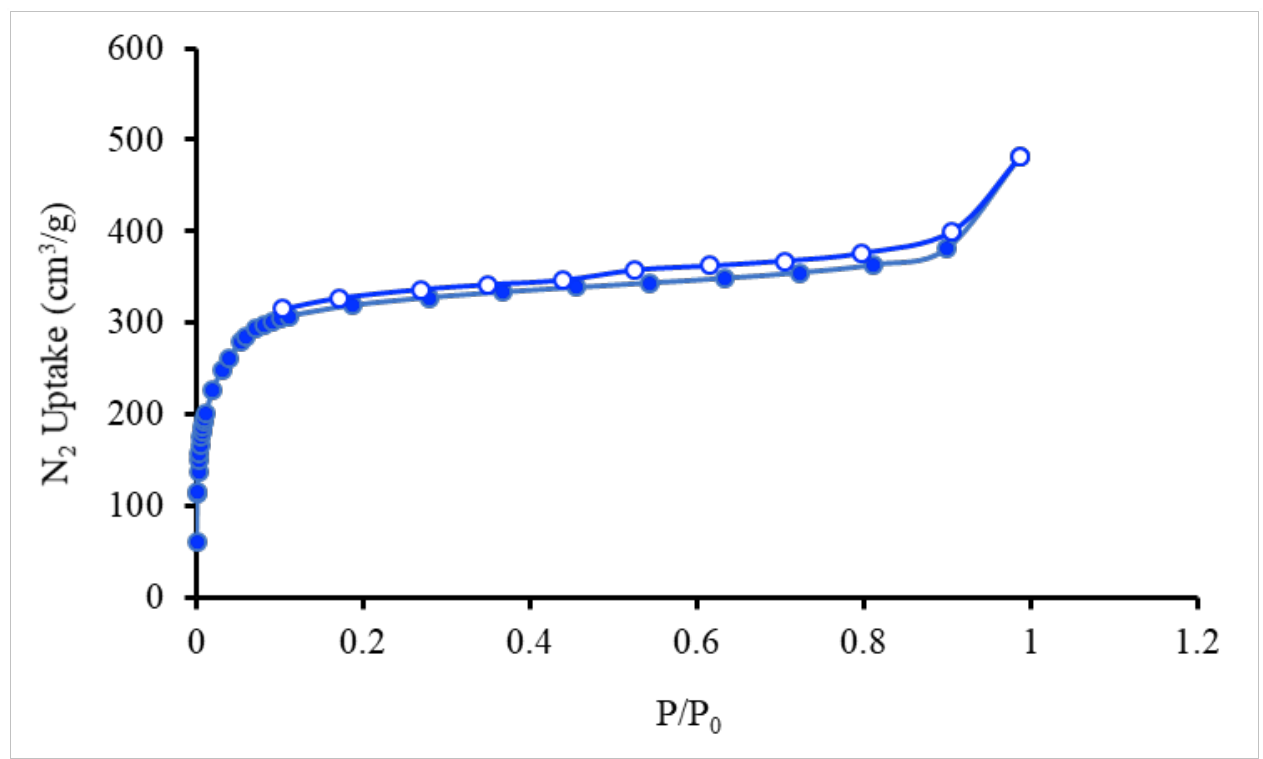

Figure S17: Nitrogen adsorption/ desorption isotherm measured at $77 \mathrm{~K}$ of Ni-DBA-2D-COF taken after reductively cleaving 2-(methylthio)naphthalene (1c) to generate $\mathbf{2 c}$.

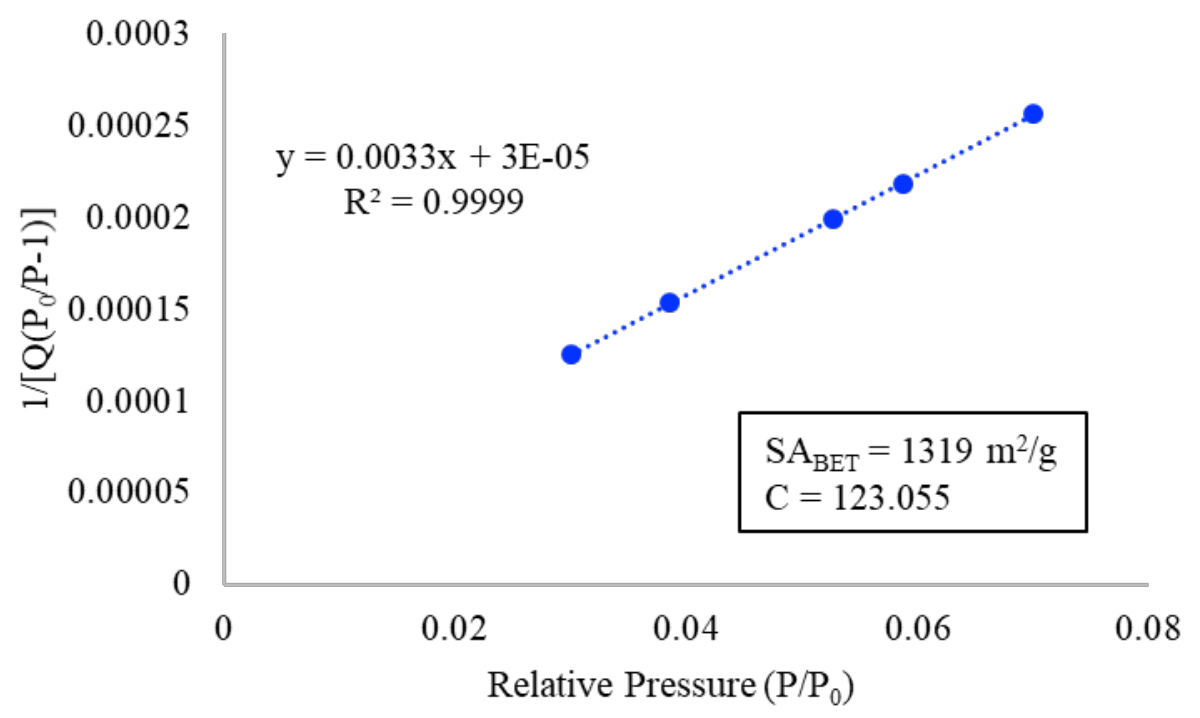

Figure S18: Linear surface area plot for Ni-DBA-2D-COF taken after reductively cleaving 2(methylthio)naphthalene (1c) to generate $\mathbf{2 c}$. 


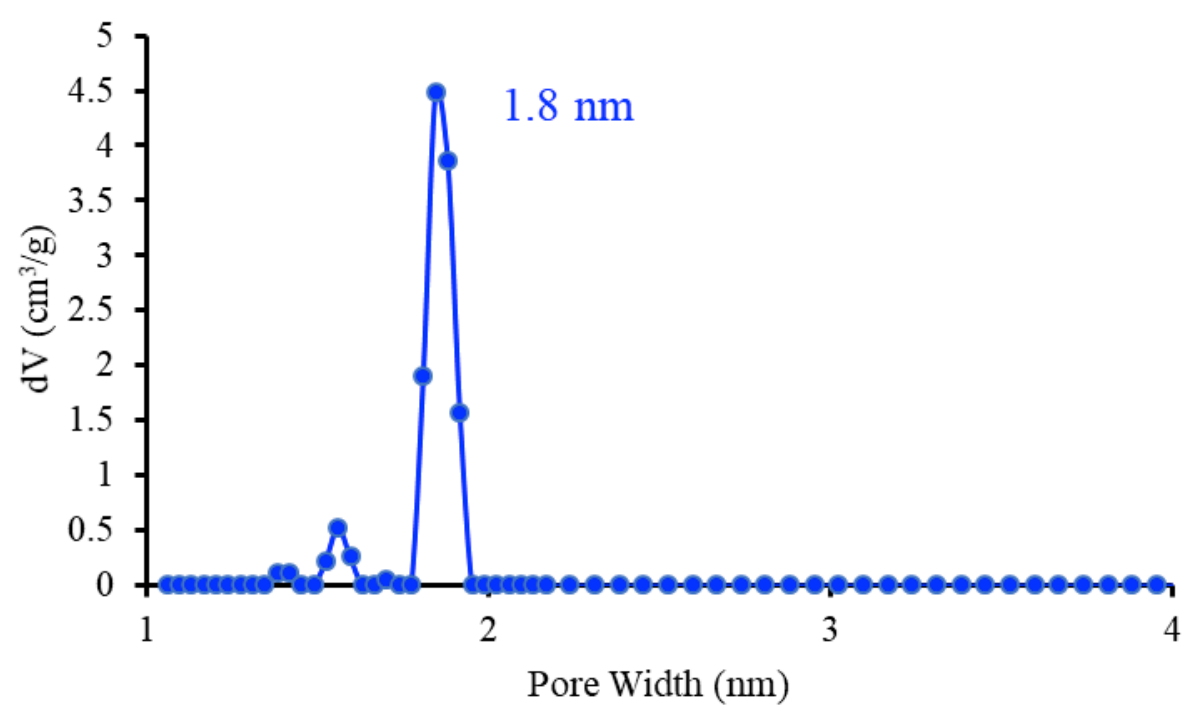

Figure S19: NLDFT pore size distribution of Ni-DBA-2D-COF taken after reductively cleaving 2(methylthio)naphthalene (1c) to generate 2c.

\section{N. Leaching Studies}

Mercury Poisoning Study. The presence of free nickel during the course of the Ni-DBA-2D-COF catalyzed HDS reaction was investigated using a mercury poisoning test, wherein any free Ni present due to leaching would form a $\mathrm{Ni}-\mathrm{Hg}$ amalgam and result in quenching of the reaction. A set of two tandem reactions were carried out following the general procedure detailed on page S17 of the ESI, using 2(methylthio)naphthalene (20 mg, $0.11 \mathrm{mmol}$ ), Ni-DBA-2D-COF (5.0 mg), Et ${ }_{3} \mathrm{SiH}(88 \mu \mathrm{L}, 0.55 \mathrm{mmol})$, in $\mathrm{PhMe}(2 \mathrm{~mL})$. In one reaction, mercury $(0.2 \mathrm{~mL})$ was added to the reaction mixture prior to heating, while the other was heated without the addition of any mercury. After the reaction time, yields for both reactions were determined by GC-FID. The reaction mixture without mercury gave a yield of $65 \%$, while the reaction with mercury gave a yield of $72 \%$. These results suggest that there is no significant leaching of $\mathrm{Ni}$ from the $\mathrm{COF}$ during the course of the reaction.

Filtrate Leaching Study. The filtrate leaching study was set up following the general procedure mentioned above using 2-(methylthio)naphthalene $(20 \mathrm{mg}, 0.11 \mathrm{mmol})$, Ni-DBA-2D-COF $(5.0 \mathrm{mg})$, $\mathrm{Et}_{3} \mathrm{SiH}(88 \mu \mathrm{L}, 0.55 \mathrm{mmol})$, in PhMe $(2 \mathrm{~mL})$. After the addition of all components, the pressure tube was sealed and placed in a pre-heated oil bath where it was stirred at $130{ }^{\circ} \mathrm{C}$. After $5 \mathrm{~h}$, the catalyst was removed by filtration in an argon filled glovebox and a yield of $30 \%$ was determined by GC. The filtrate was then transferred to a separate pressure tube which was sealed and placed back into the oil bath at 130 ${ }^{\circ} \mathrm{C}$. No additional product was observed by $\mathrm{GC}$ after $17 \mathrm{~h}$ of heating the reaction filtrate, suggesting that there is negligible leaching of Ni from the solid Ni-DBA-2D-COF catalyst.

ICP-MS of Filtrate. In this study, a pressure tube was charged with Ni-DBA-2D-COF (5 mg) in PhMe (2 $\mathrm{mL}$ ) in an argon filled glovebox. The pressure tube was sealed and placed in a pre-heated oil bath where it was stirred at $130{ }^{\circ} \mathrm{C}$ for $14 \mathrm{~h}$. After completion of the reaction time, the solution was cooled to room 
temperature and the solid catalyst was removed by filtering through celite. The filtrate was concentrated down and the resulting solids were dispersed in $10 \mathrm{~mL}$ of DI $\mathrm{H}_{2} \mathrm{O}$. ICP-MS analysis of the aqueous solution showed a Ni concentration of $3 \mathrm{ppb}$, corresponding to $\sim 0.02 \%$ of the original Ni-content of NiDBA-2D-COF.

\section{O. Mechanistic Investigations}

\section{Computational Insight into Oxidative Addition Step}

Computational Details. All calculations were performed using Gaussian09, Revision E.01 for the Linux operating system. ${ }^{7}$ Density functional theory calculations were carried out using a combination of Becke's 1988 gradient-corrected exchange functional $^{8}$ and Perdew's 1986 electron correlation functional $^{9}$ (BP86). A mixed-basis set was employed, using the LANL2DZ(p,d) double zeta basis set and effective core potentials for nickel, ${ }^{10-12}$ Gaussian09's internal 6-31+G(d) basis set for sulfur, and Gaussian09's internal 6-31G(d) basis set for carbon and hydrogen. The crystallographically determined geometry of NiDBA[12] was used as a starting point for all calculations. ${ }^{13}$ All geometry optimizations starting from Ni$\mathrm{DBA}[12]$ with an aryl thioether bound to the Ni center resulted in optimized geometries in which the thioether substrate had dissociated from the $\mathrm{Ni}$ ion, leading to the conclusion that thioether substrates do not bind to the coordinatively saturated DBA-Ni(0) complex. On the other hand, starting a calculation from a position in which the $\mathrm{C}$ (aryl)-SMe bond had oxidatively added to the Ni center while it remained in the tris(alkynyl) binding pocket resulted an optimized geometry in which the $\mathrm{Ni}$ ion had popped out of the tris(alkynyl) binding site. In the optimized geometry shown in Figure S20, the Ni center is threecoordinate and binds to a single alkyne fragment in addition to the aryl and thiolate moieties resulting from oxidative addition. This oxidative addition product was found to be $\sim 30 \mathrm{kcal} / \mathrm{mol}$ higher in energy compared to the dissociated Ni-DBA[12] + PhSMe combination described above. XYZ coordinates of optimized geometries are provided in Table S3 and S4.
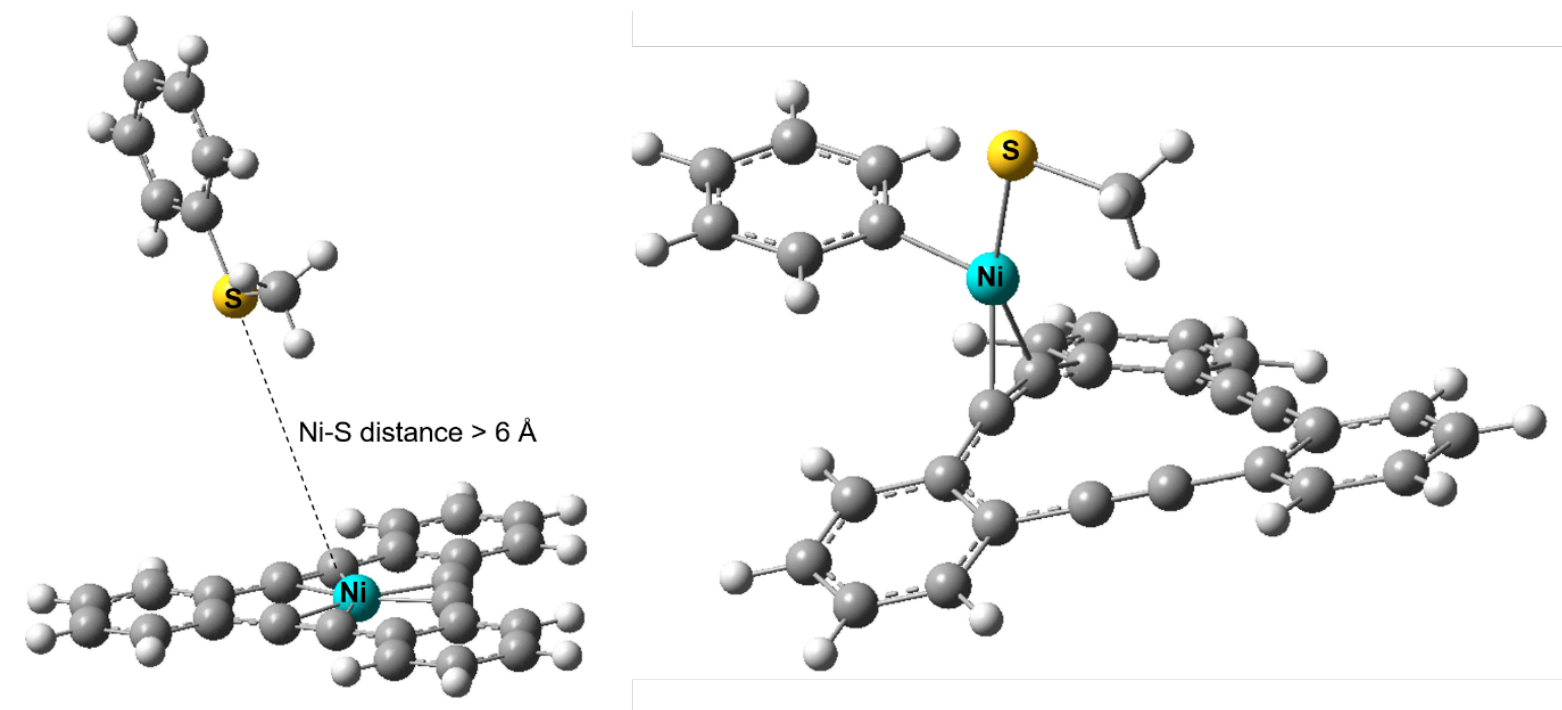

Figure S20: Computational model of thioanisole coordination to DBA-Ni(0) (left), and the product of oxidative addition of thioanisole to DBA-Ni (right). The model shows that the thioanisole does not bind to DBA-Ni(0), and that nickel must dissociate from its planar tris(alkynyl) binding site in order to oxidative add the $\mathrm{C}(\operatorname{aryl})-\mathrm{SMe}$ bond. The oxidative addition product features coordination of $\mathrm{Ni}$ to only one alkyne ligand and is $30 \mathrm{kcal} / \mathrm{mol}$ higher in energy than DBA-Ni(0) $+\mathrm{PhSMe}$. 
Table S3: XYZ coordinates of DFT-optimized geometry of Ni-DBA[12] + PhSMe oxidative addition product.

Energy: -1760.797142 Hartrees

\begin{tabular}{|c|c|c|c|}
\hline Symbol & $\mathrm{X}$ & $\mathrm{Y}$ & $\mathrm{Z}$ \\
\hline $\mathrm{Ni}$ & 1.207972 & -0.06295 & 0.844936 \\
\hline $\mathrm{C}$ & -1.99586 & -2.00151 & -0.72345 \\
\hline $\mathrm{C}$ & -2.99628 & -1.34548 & -0.27408 \\
\hline $\mathrm{C}$ & -4.08188 & -0.60895 & 0.202158 \\
\hline $\mathrm{C}$ & -4.03484 & 0.830008 & 0.225 \\
\hline $\mathrm{C}$ & -2.86822 & 1.516318 & -0.26459 \\
\hline $\mathrm{C}$ & -1.88847 & 2.054306 & -0.69425 \\
\hline $\mathrm{C}$ & -0.70581 & 2.689096 & -1.21204 \\
\hline $\mathrm{C}$ & 0.516804 & 1.947868 & -1.33867 \\
\hline $\mathrm{C}$ & 0.596035 & 0.595049 & -0.89876 \\
\hline $\mathrm{C}$ & 0.57095 & -0.70517 & -0.89586 \\
\hline $\mathrm{C}$ & 0.393625 & -2.05205 & -1.33035 \\
\hline $\mathrm{C}$ & -0.89008 & -2.69252 & -1.22005 \\
\hline $\mathrm{C}$ & -5.25213 & -1.2568 & 0.665385 \\
\hline $\mathrm{C}$ & -6.34524 & -0.52175 & 1.139345 \\
\hline $\mathrm{C}$ & -6.29105 & 0.883926 & 1.163415 \\
\hline $\mathrm{C}$ & -5.14841 & 1.553226 & 0.713344 \\
\hline $\mathrm{C}$ & -0.73557 & 4.043793 & -1.62036 \\
\hline $\mathrm{C}$ & 0.404947 & 4.65933 & -2.14477 \\
\hline $\mathrm{C}$ & 1.601283 & 3.930551 & -2.27963 \\
\hline $\mathrm{C}$ & 1.655898 & 2.590407 & -1.87374 \\
\hline $\mathrm{C}$ & 1.491526 & -2.78899 & -1.83627 \\
\hline $\mathrm{C}$ & 1.33452 & -4.12084 & -2.24405 \\
\hline $\mathrm{C}$ & 0.081275 & -4.74896 & -2.14276 \\
\hline $\mathrm{C}$ & -1.01522 & -4.04214 & -1.63503 \\
\hline $\mathrm{H}$ & -5.2833 & -2.3508 & 0.648614 \\
\hline $\mathrm{H}$ & -7.23852 & -1.04325 & 1.497541 \\
\hline $\mathrm{H}$ & -7.14446 & 1.456358 & 1.540082 \\
\hline $\mathrm{H}$ & -5.10363 & 2.647505 & 0.724216 \\
\hline $\mathrm{H}$ & -1.6773 & 4.595996 & -1.52569 \\
\hline $\mathrm{H}$ & 0.363291 & 5.709195 & -2.45518 \\
\hline $\mathrm{H}$ & 2.493741 & 4.407877 & -2.69505 \\
\hline $\mathrm{H}$ & 2.58477 & 2.018028 & -1.95368 \\
\hline $\mathrm{H}$ & 2.468292 & -2.29983 & -1.90014 \\
\hline $\mathrm{H}$ & 2.192238 & -4.6686 & -2.64818 \\
\hline $\mathrm{H}$ & -0.04448 & -5.78813 & -2.46725 \\
\hline $\mathrm{H}$ & -1.99853 & -4.51541 & -1.5599 \\
\hline
\end{tabular}




\begin{tabular}{|l|r|r|r|}
\hline S & 1.20585 & -0.10129 & 2.990871 \\
\hline C & 3.076366 & -0.00051 & 0.980321 \\
\hline C & 3.806102 & -1.19635 & 1.079404 \\
\hline C & 3.729956 & 1.235665 & 0.827052 \\
\hline C & 5.210426 & -1.15421 & 0.967973 \\
\hline H & 3.294552 & -2.14983 & 1.250851 \\
\hline C & 5.134617 & 1.261097 & 0.718175 \\
\hline H & 3.163253 & 2.171544 & 0.799235 \\
\hline C & 5.875061 & 0.07038 & 0.785171 \\
\hline H & 5.781735 & -2.08738 & 1.030948 \\
\hline H & 5.643792 & 2.224582 & 0.587153 \\
\hline H & 6.968642 & 0.095868 & 0.709216 \\
\hline C & -0.6468 & -0.08731 & 3.090451 \\
\hline H & -0.98428 & 0.835177 & 3.590122 \\
\hline H & -1.11097 & -0.13035 & 2.086188 \\
\hline H & -0.98685 & -0.97033 & 3.657822 \\
\hline
\end{tabular}

Table S4: XYZ coordinates of DFT-optimized geometry of dissociated Ni-DBA[12] + PhSMe combination.

Energy: -1760.844945 Hartrees

\begin{tabular}{|l|r|r|r|}
\hline Symbol & X & \multicolumn{1}{l|}{ Y } & \multicolumn{1}{l|}{} \\
\hline $\mathrm{Ni}$ & 2.175863 & 0.015836 & -0.42077 \\
\hline $\mathrm{C}$ & 2.605824 & 1.862479 & 0.147737 \\
\hline $\mathrm{C}$ & 3.239878 & 1.051072 & 0.900076 \\
\hline $\mathrm{C}$ & 3.999919 & 0.24911 & 1.819731 \\
\hline $\mathrm{C}$ & 3.86104 & -1.16967 & 1.6147 \\
\hline $\mathrm{C}$ & 2.987766 & -1.51684 & 0.526555 \\
\hline $\mathrm{C}$ & 2.239431 & -1.97038 & -0.40132 \\
\hline $\mathrm{C}$ & 1.425756 & -2.5994 & -1.40616 \\
\hline $\mathrm{C}$ & 0.706365 & -1.67638 & -2.24566 \\
\hline $\mathrm{C}$ & 0.936764 & -0.2939 & -1.92477 \\
\hline $\mathrm{C}$ & 1.052288 & 0.964362 & -1.74904 \\
\hline $\mathrm{C}$ & 1.095163 & 2.398433 & -1.65684 \\
\hline $\mathrm{C}$ & 1.954635 & 2.894337 & -0.61288 \\
\hline $\mathrm{C}$ & 4.828827 & 0.728763 & 2.856226 \\
\hline $\mathrm{C}$ & 5.508053 & -0.18313 & 3.676776 \\
\hline $\mathrm{C}$ & 5.371424 & -1.57239 & 3.476142 \\
\hline $\mathrm{C}$ & 4.553712 & -2.07011 & 2.451489 \\
\hline $\mathrm{C}$ & 1.286826 & -3.98843 & -1.61355 \\
\hline
\end{tabular}




\begin{tabular}{|l|r|r|r|}
\hline C & 0.448344 & -4.45517 & -2.63585 \\
\hline $\mathrm{C}$ & -0.25642 & -3.5511 & -3.45728 \\
\hline $\mathrm{C}$ & -0.13248 & -2.16727 & -3.26864 \\
\hline $\mathrm{C}$ & 0.391111 & 3.307561 & -2.47483 \\
\hline $\mathrm{C}$ & 0.538968 & 4.68583 & -2.26381 \\
\hline $\mathrm{C}$ & 1.382704 & 5.171395 & -1.2434 \\
\hline $\mathrm{C}$ & 2.089477 & 4.285357 & -0.41794 \\
\hline $\mathrm{H}$ & 4.934109 & 1.807629 & 3.010772 \\
\hline $\mathrm{H}$ & 6.151366 & 0.188752 & 4.481742 \\
\hline $\mathrm{H}$ & 5.909227 & -2.27081 & 4.12657 \\
\hline $\mathrm{H}$ & 4.4469 & -3.14823 & 2.29289 \\
\hline $\mathrm{H}$ & 1.833873 & -4.68923 & -0.97436 \\
\hline $\mathrm{H}$ & 0.339731 & -5.53336 & -2.79634 \\
\hline $\mathrm{H}$ & -0.90818 & -3.93241 & -4.25088 \\
\hline $\mathrm{H}$ & -0.67963 & -1.46323 & -3.90397 \\
\hline $\mathrm{H}$ & -0.2641 & 2.928982 & -3.2661 \\
\hline $\mathrm{H}$ & -0.00756 & 5.391708 & -2.8987 \\
\hline $\mathrm{H}$ & 1.486642 & 6.25141 & -1.09231 \\
\hline $\mathrm{H}$ & 2.744116 & 4.65976 & 0.375924 \\
\hline $\mathrm{S}$ & -4.15229 & -0.00853 & 0.640968 \\
\hline $\mathrm{C}$ & -5.9159 & -0.01532 & 0.936869 \\
\hline $\mathrm{C}$ & -6.74457 & 0.117618 & -0.201 \\
\hline $\mathrm{C}$ & -6.50994 & -0.13475 & 2.21031 \\
\hline $\mathrm{C}$ & -8.13796 & 0.130026 & -0.0626 \\
\hline $\mathrm{H}$ & -6.2914 & 0.206902 & -1.19546 \\
\hline $\mathrm{C}$ & -7.90897 & -0.12446 & 2.336355 \\
\hline $\mathrm{H}$ & -5.89025 & -0.23642 & 3.106113 \\
\hline $\mathrm{C}$ & -8.7299 & 0.007613 & 1.206643 \\
\hline $\mathrm{H}$ & -8.76515 & 0.23075 & -0.9558 \\
\hline $\mathrm{H}$ & -8.35713 & -0.2189 & 3.332352 \\
\hline $\mathrm{H}$ & -9.81996 & 0.015762 & 1.313872 \\
\hline $\mathrm{C}$ & -3.43129 & -0.2801 & 2.302042 \\
\hline $\mathrm{H}$ & -3.76892 & -1.23744 & 2.732454 \\
\hline $\mathrm{H}$ & -2.3419 & -0.3214 & 2.14234 \\
\hline & -3.66044 & 0.551828 & 2.988469 \\
\hline
\end{tabular}




\section{Isolation of Dimethylethyl(methylthio)silane Byproduct}<smiles>CC[Si](C)(C)SC</smiles>

Synthesis of Dimethylethyl(methylthio)silane: Sodium thiomethoxide (125 mg, $1.78 \mathrm{mmol})$ in THF (3 $\mathrm{mL})$ was cooled to $-78^{\circ} \mathrm{C}$ followed by the dropwise addition of chlorodimethylethylsilane $(0.25 \mathrm{~mL}, 1.78$ mmol). The solution was then stirred at room temperature for $3 \mathrm{~h}$. An aliquot $(1.5 \mathrm{~mL})$ was then filtered through a pipet of silica, washing with EtOAc $(1.5 \mathrm{~mL})$. The filtered solution was then further filtered through a nylon membrane disc filter prior to analysis by GC-MS.

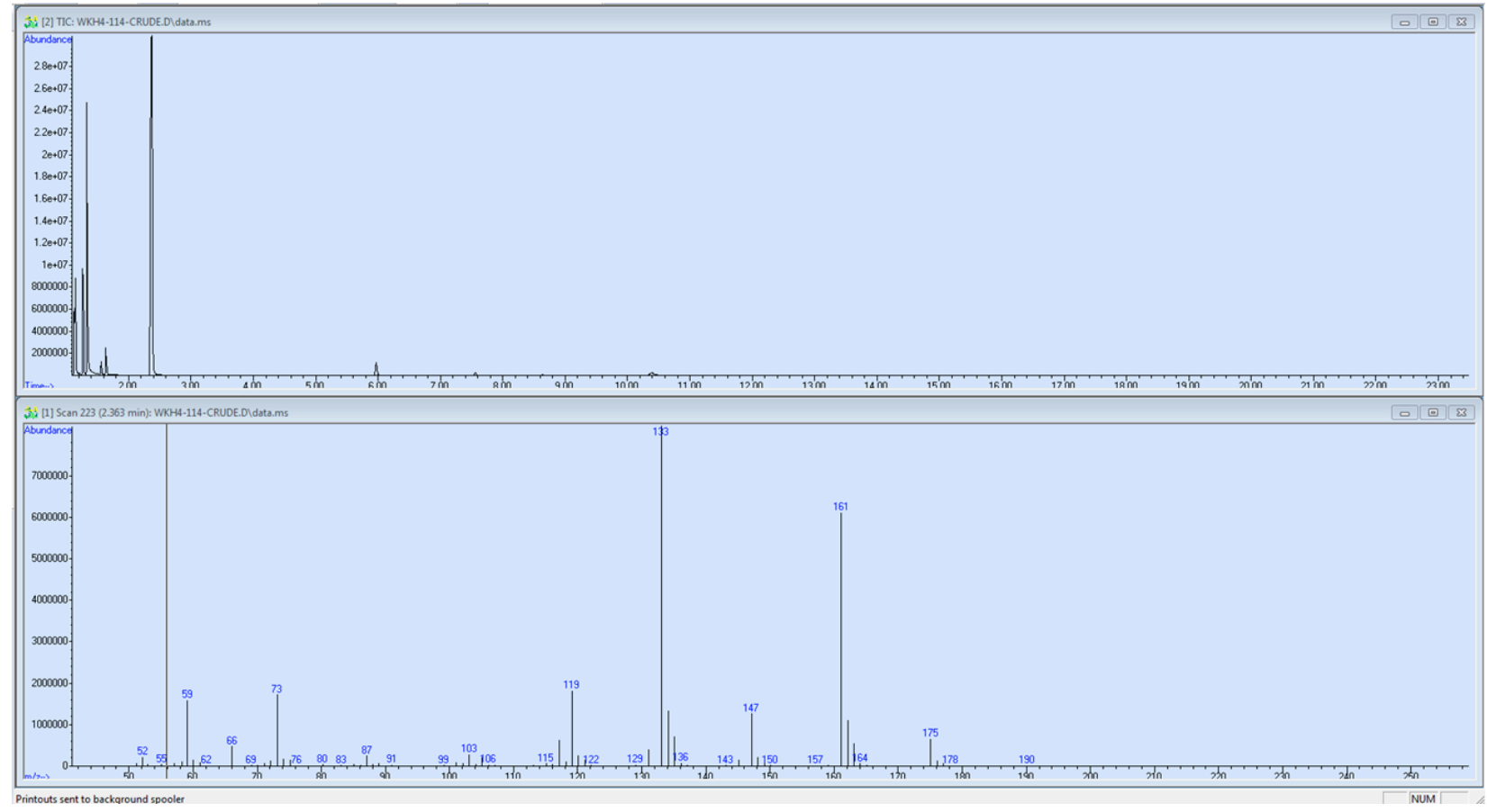

Figure S21: GC-MS spectra of dimethylethyl(methylthio)silane as directly synthesized.

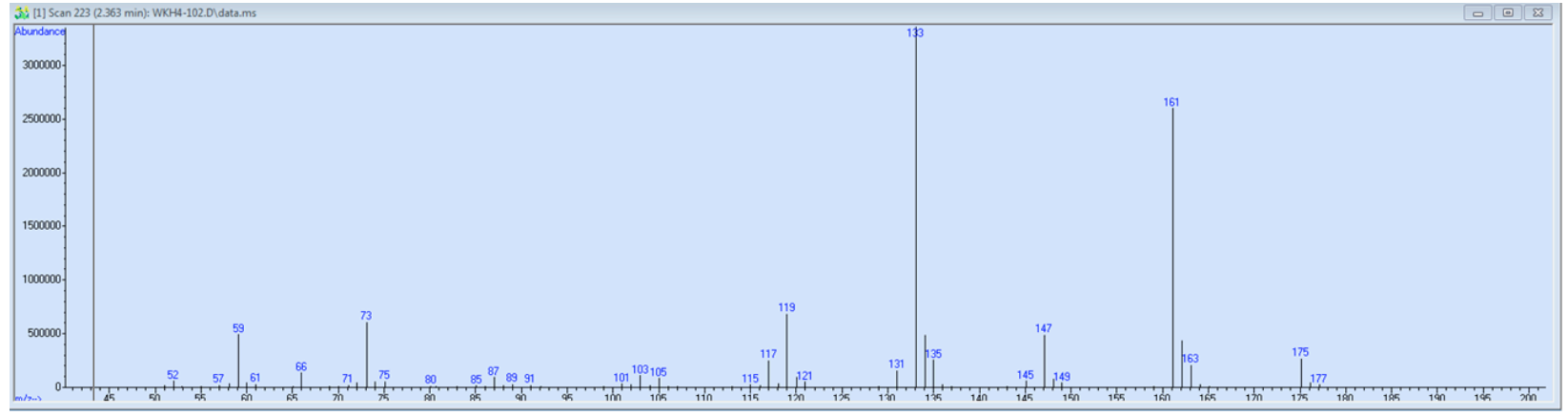

Figure S22: GC-MS spectra of dimethylethyl(methylthio)silane as seen in the crude reaction mixture of the Ni-DBA catalyzed hydrodesulurization of 4-chlorothioanisole. 


\section{Proposed Catalytic Cycle}

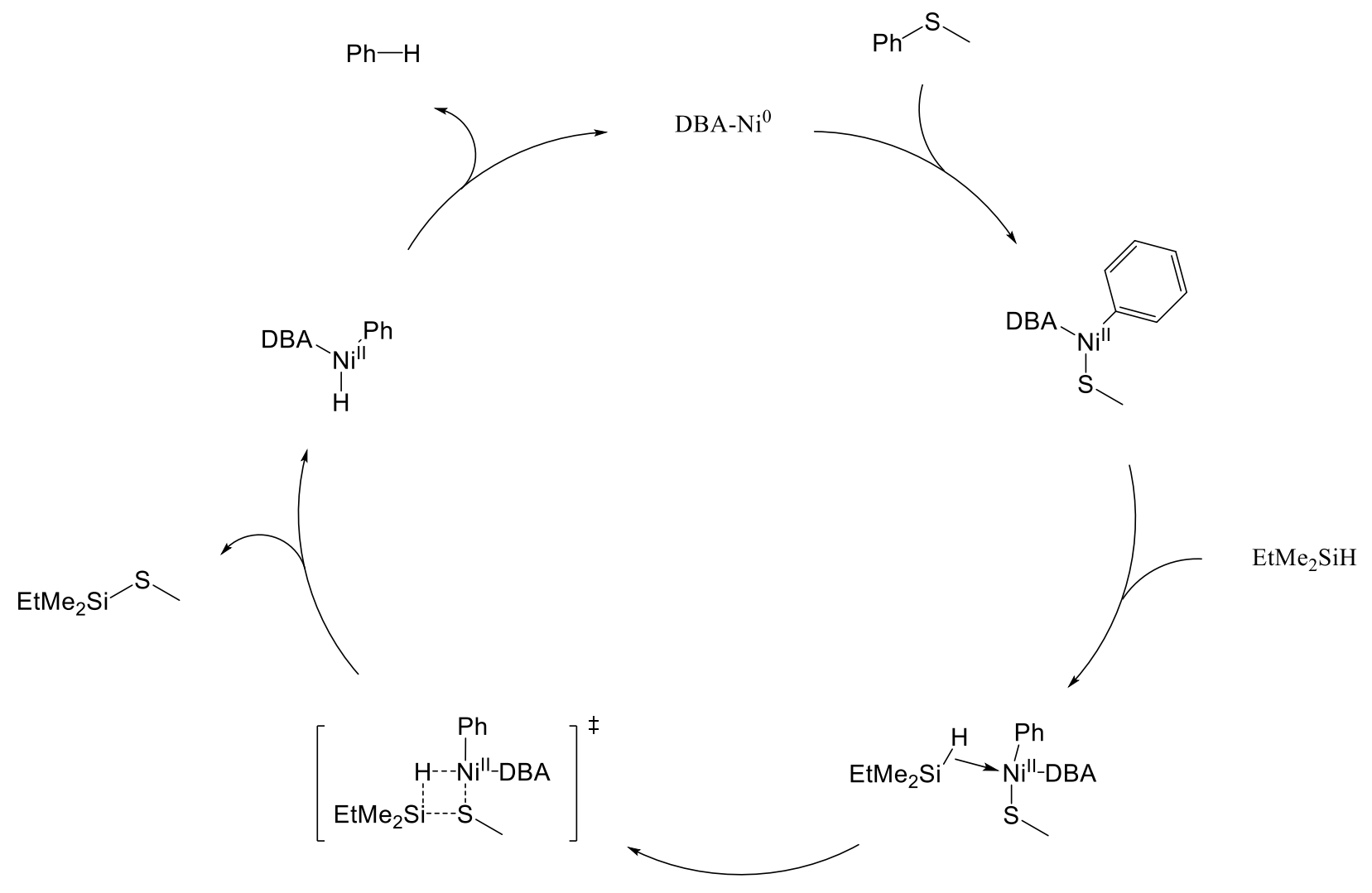

Figure S23: Proposed catalytic cycle for the reductive cleavage of aryl methylthioethers. 


\section{P. GC-FID Chromatograms}

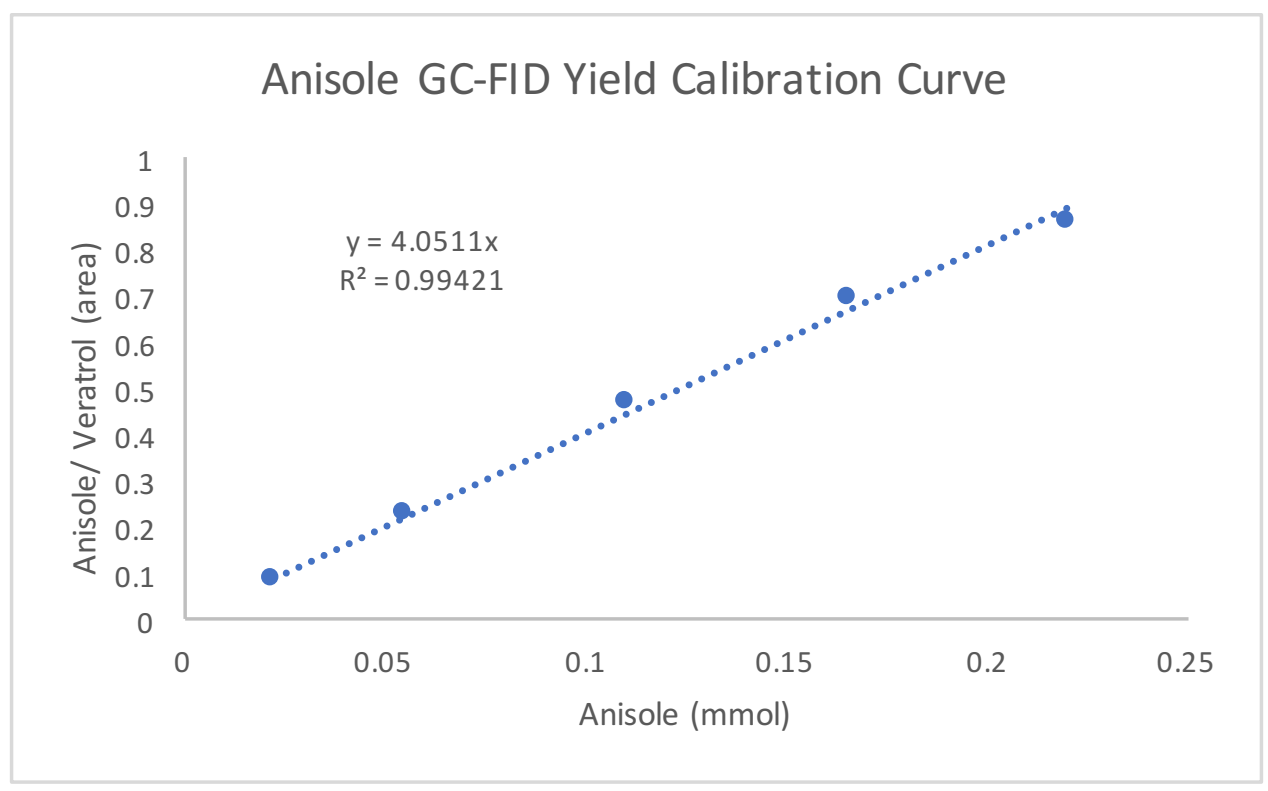

Figure S24: GC-FID calibration curve for the determination of anisole (1.7 $\mathrm{min})$ yield with veratrole (4.9 $\mathrm{min}$ ) as the internal standard, using GC-FID method [80-RAMP]. 


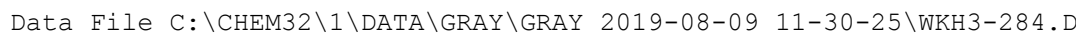

Sample Name: WKH3-284
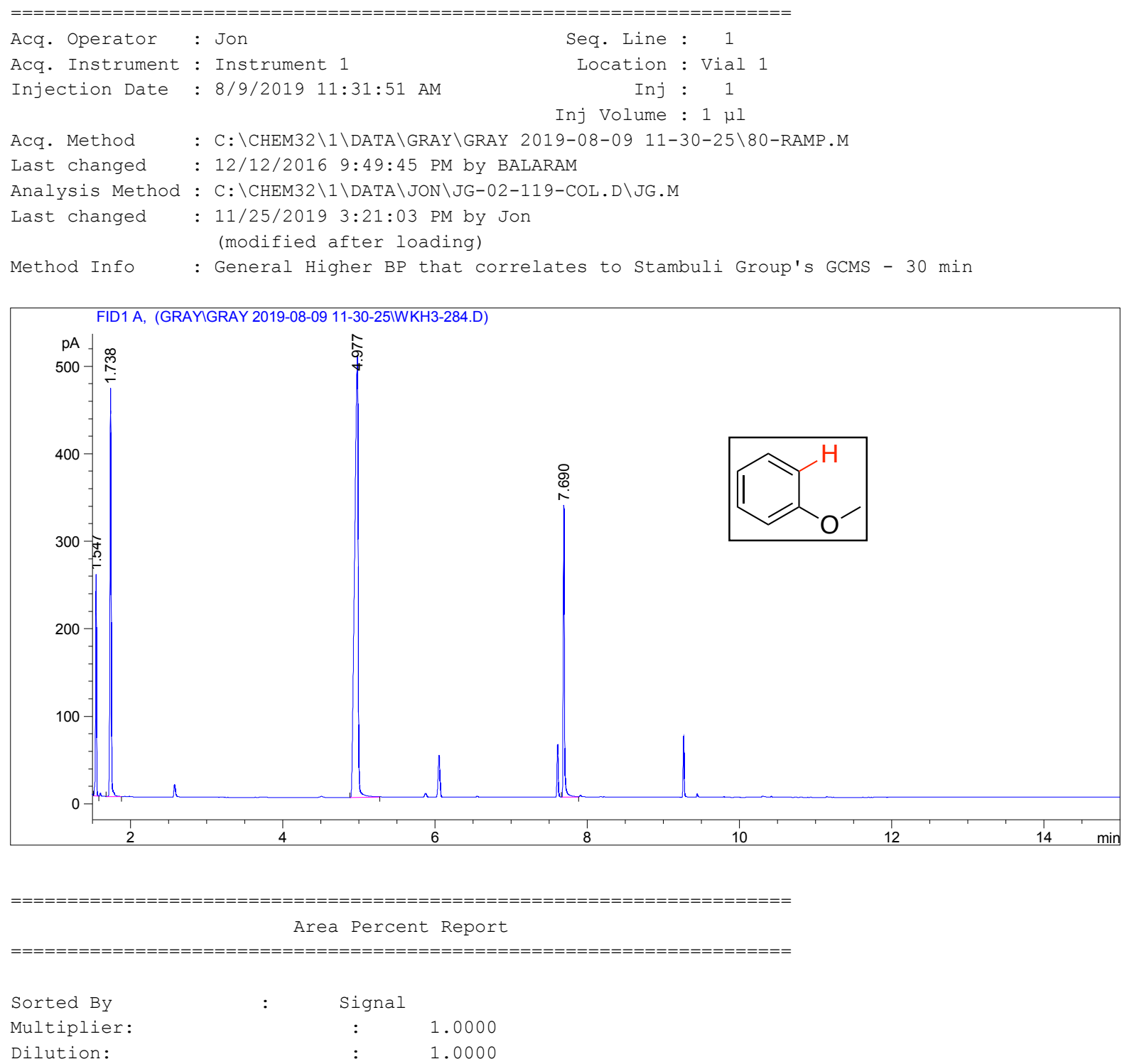

rer

Use Multiplier \& Dilution Factor with ISTDs

Signal 1: FID1 A,

\begin{tabular}{|c|c|c|c|c|c|c|}
\hline $\begin{array}{c}\text { Peak } \\
\#\end{array}$ & $\begin{array}{c}\text { RetTime } \\
\text { [min] }\end{array}$ & Type & $\begin{array}{l}\text { Width } \\
\text { [min] }\end{array}$ & $\begin{array}{r}\text { Area } \\
{\left[\mathrm{pA}^{\star} \mathrm{s}\right]}\end{array}$ & $\begin{array}{l}\text { Height } \\
{[\mathrm{pA}]}\end{array}$ & $\begin{array}{c}\text { Area } \\
\frac{\circ}{0}\end{array}$ \\
\hline & & & & ---------- & -------1 & -------- \\
\hline 1 & 1.547 & BV & 0.0141 & 223.89148 & 253.02419 & 8.17062 \\
\hline 2 & 1.738 & VV & 0.0177 & 536.85211 & 466.39615 & 19.59171 \\
\hline 3 & 4.977 & $\mathrm{BB}$ & 0.0466 & 1603.78540 & 504.47464 & 58.52804 \\
\hline
\end{tabular}




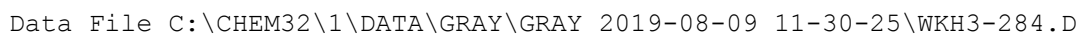

Sample Name: WKH3-284

\begin{tabular}{|c|c|c|c|c|c|c|}
\hline $\begin{array}{c}\text { Peak } \\
\#\end{array}$ & $\begin{array}{c}\text { RetTime } \\
\text { [min] }\end{array}$ & Type & $\begin{array}{l}\text { Width } \\
\text { [min] }\end{array}$ & $\begin{array}{r}\text { Area } \\
{\left[\mathrm{pA}{ }^{\star} \mathrm{s}\right]}\end{array}$ & $\begin{array}{l}\text { Height } \\
{[\mathrm{pA}]}\end{array}$ & $\begin{array}{c}\text { Area } \\
\frac{\circ}{\circ}\end{array}$ \\
\hline--- & |------- & ---- & ------- & ---------- & ---------- & | -------- \\
\hline 4 & 7.690 & VV & 0.0171 & 375.67126 & 334.10779 & 13.70963 \\
\hline Tota] & : & & & 2740.20026 & 1558.00276 & \\
\hline
\end{tabular}

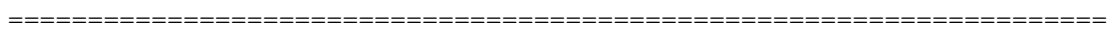

$\star * \star$ End of Report $* * *$

Figure S25: Typical GC-FID chromatogram for the internal standard determination of yield for anisole. 


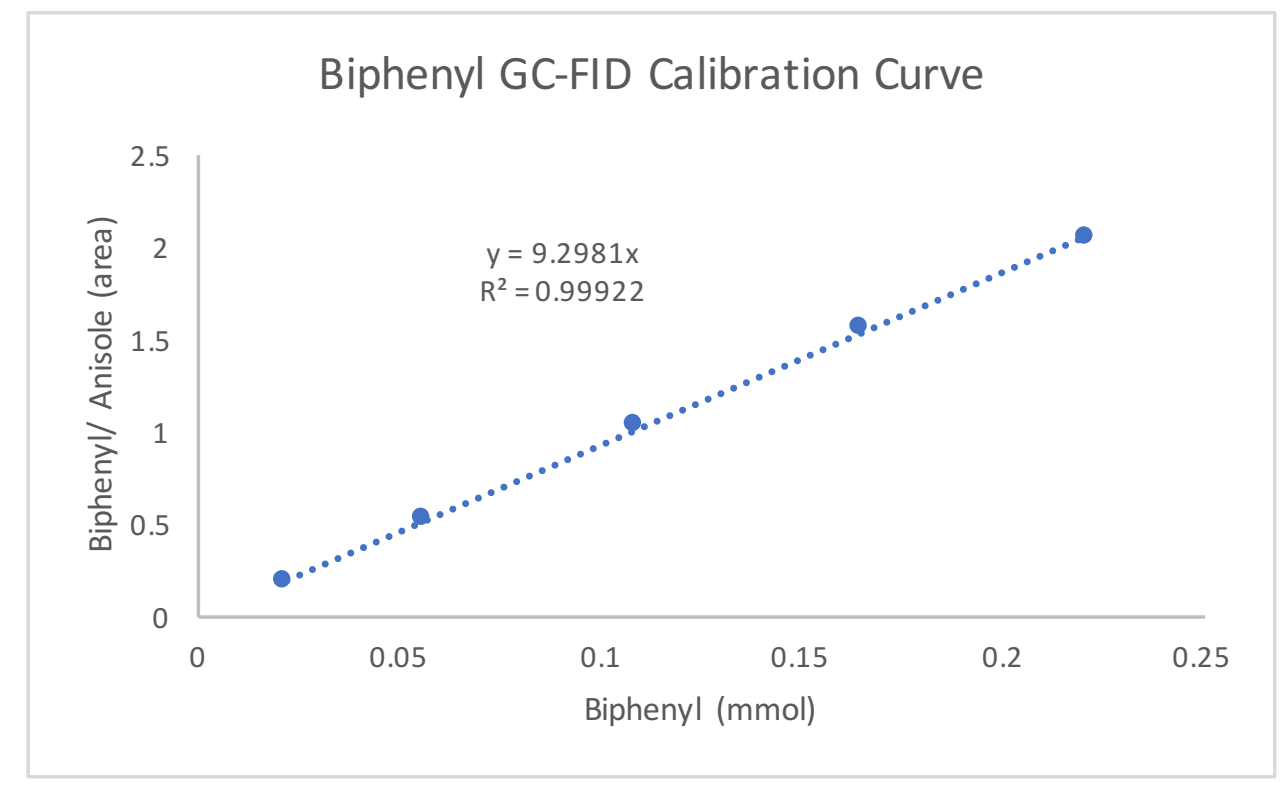

Figure S26: GC-FID calibration curve for the determination of biphenyl (5.2 min) yield with anisole (1.3 min) as the internal standard, using GC-FID method [100-RAMP]. 


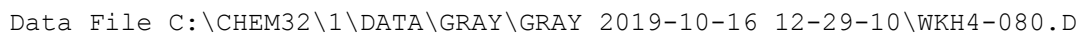

Sample Name: WKH4-080
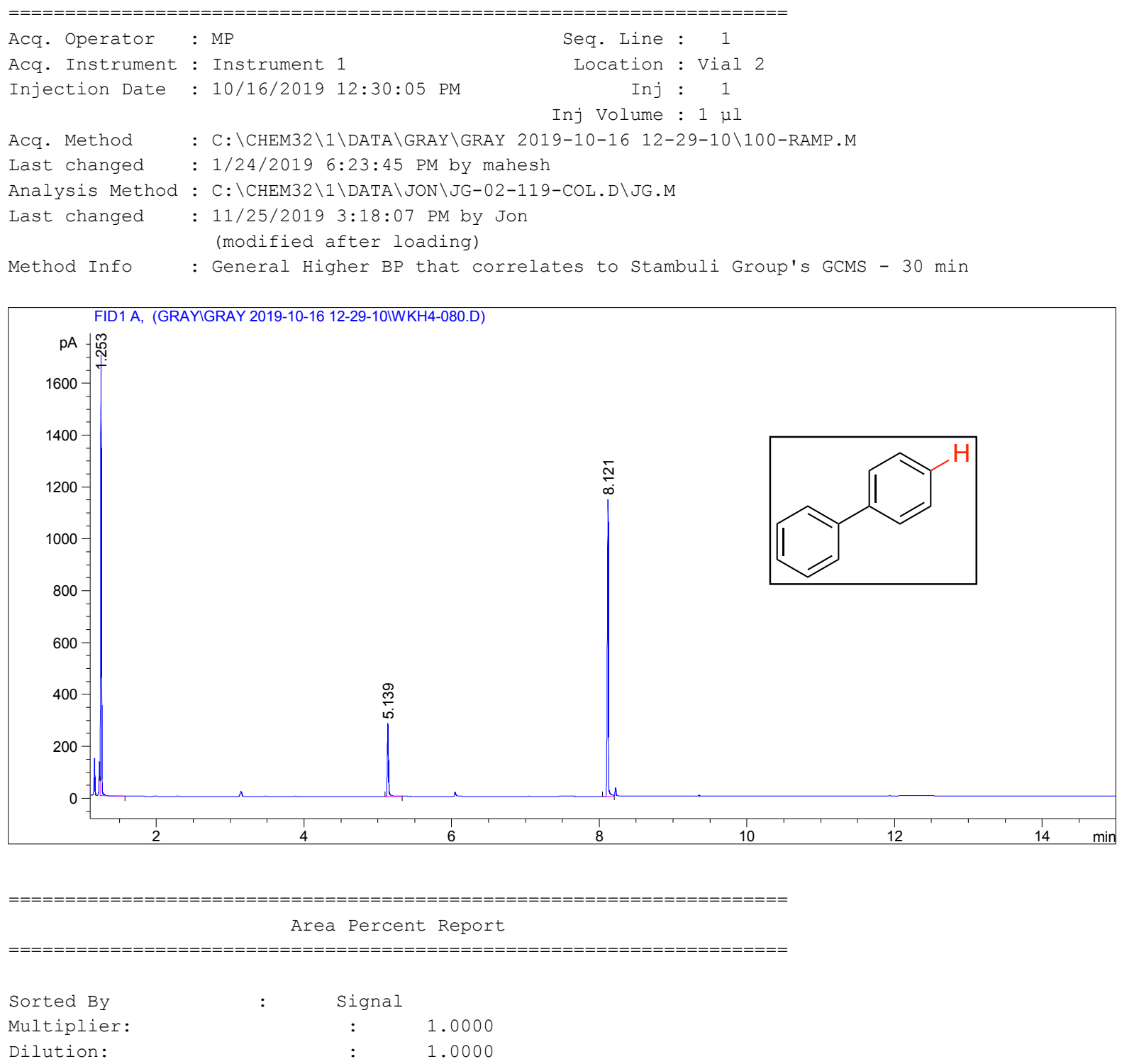

Use Multiplier \& Dilution Factor with ISTDs

Signal 1: FID1 A,

\begin{tabular}{|c|c|c|c|c|c|c|}
\hline $\begin{array}{c}\text { Peak } \\
\#\end{array}$ & $\begin{array}{c}\text { RetTime } \\
\text { [min] }\end{array}$ & Type & $\begin{array}{l}\text { Width } \\
\text { [min] }\end{array}$ & $\begin{array}{r}\text { Area } \\
{\left[\mathrm{pA}{ }^{\star} \mathrm{s}\right]}\end{array}$ & $\begin{array}{l}\text { Height } \\
{[\mathrm{pA}]}\end{array}$ & $\begin{array}{c}\text { Area } \\
\frac{\circ}{0}\end{array}$ \\
\hline & & & & | --------- & $|----------|$ & -------- \\
\hline 1 & 1.253 & VB $S$ & 0.0129 & 1372.87268 & 1699.65747 & 48.15897 \\
\hline 2 & 5.139 & VB & 0.0170 & 304.89401 & 279.74268 & 10.69537 \\
\hline 3 & 8.121 & VV & 0.0157 & 1172.94336 & 1145.50513 & 41.14566 \\
\hline
\end{tabular}




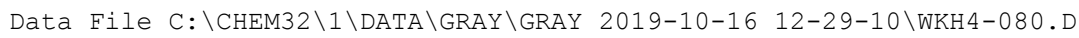

Sample Name: WKH4-080

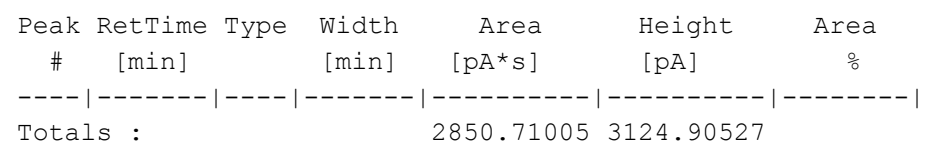

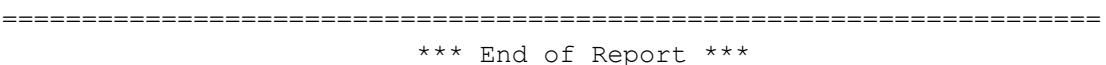

Instrument 1 11/25/2019 3:18:09 PM Jon

Page 2 of 2

Figure S27: Typical GC-FID chromatogram for the internal standard determination of yield for biphenyl. 


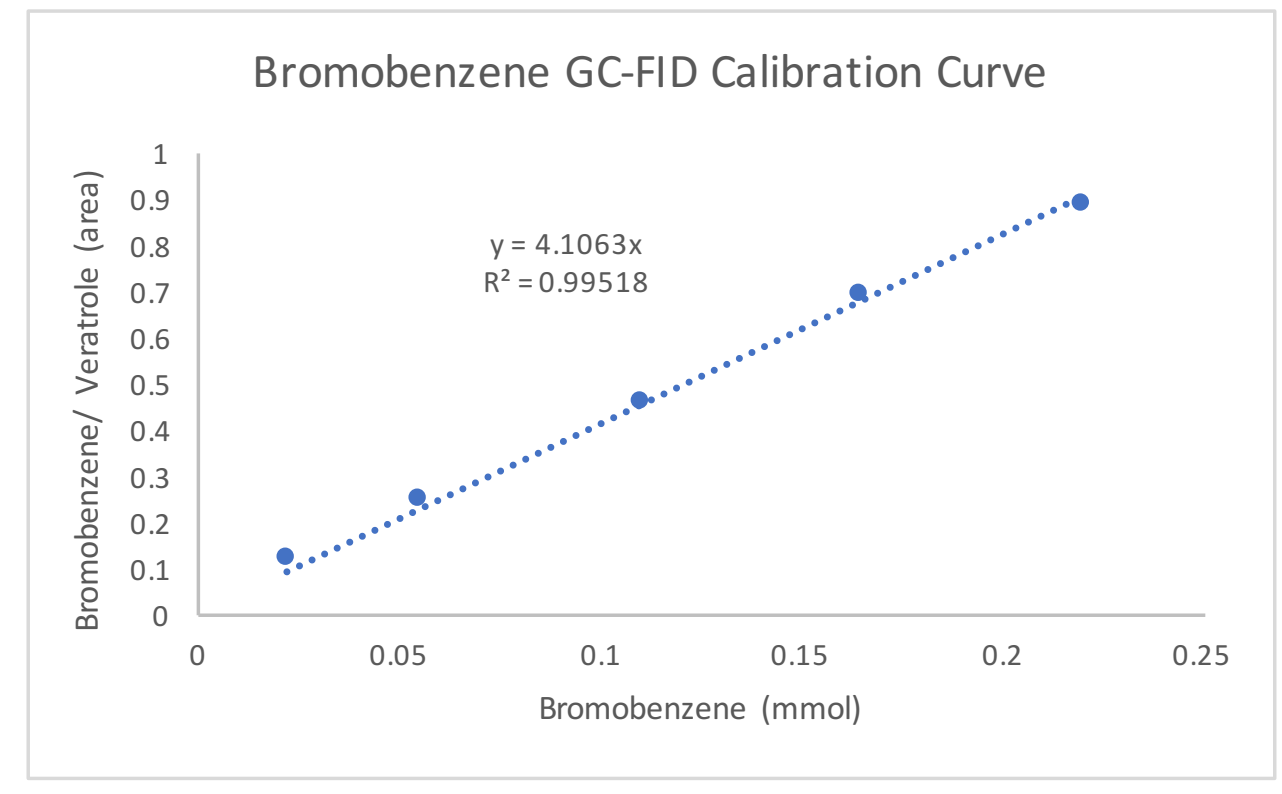

Figure S28: GC-FID calibration curve for the determination of bromobenzene (1.8 min) yield with veratrole (5.0 min) as the internal standard, using GC-FID method [80-RAMP]. 


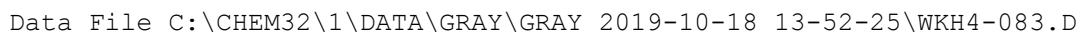

Sample Name: WKH4-083
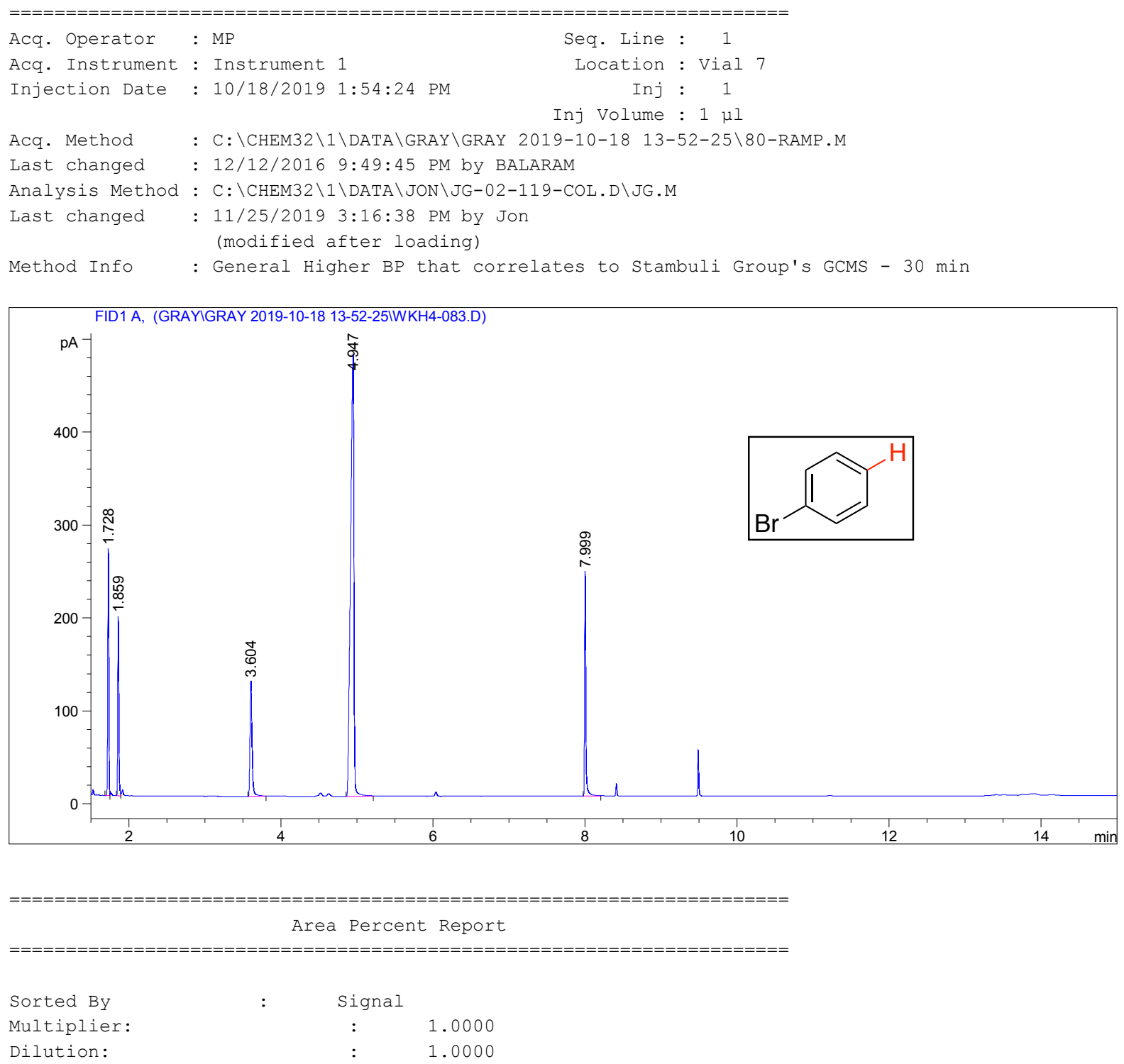

1.0000

Use Multiplier \& Dilution Factor with ISTDs

Signal 1: FID1 A,

\begin{tabular}{|c|c|c|c|c|c|c|}
\hline $\begin{array}{c}\text { Peak } \\
\quad \#\end{array}$ & $\begin{array}{c}\text { RetTime } \\
\text { [min] }\end{array}$ & Type & $\begin{array}{l}\text { Width } \\
\text { [min] }\end{array}$ & $\begin{array}{r}\text { Area } \\
{\left[\mathrm{pA}^{\star} \mathrm{s}\right]}\end{array}$ & $\begin{array}{l}\text { Height } \\
{[\mathrm{pA}]}\end{array}$ & $\begin{array}{c}\text { Area } \\
\quad \%\end{array}$ \\
\hline & & & & --------- & ------ & ----- \\
\hline 1 & 1.728 & VV & 0.0159 & 264.70416 & 265.80780 & 10.89550 \\
\hline 2 & 1.859 & VV & 0.0164 & 201.41902 & 192.95309 & 8.29062 \\
\hline 3 & 3.604 & $\mathrm{BB}$ & 0.0292 & 235.92696 & 123.71288 & 9.71100 \\
\hline
\end{tabular}




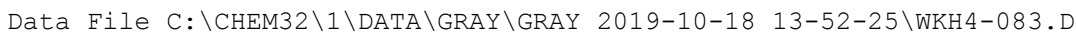

Sample Name: WKH4-083

\begin{tabular}{|c|c|c|c|c|c|c|}
\hline $\begin{array}{c}\text { Peak } \\
\#\end{array}$ & $\begin{array}{c}\text { RetTime } \\
\text { [min] }\end{array}$ & Type & $\begin{array}{l}\text { Width } \\
\text { [min] }\end{array}$ & $\begin{array}{r}\text { Area } \\
{\left[\mathrm{pA}^{\star} \mathrm{s}\right]}\end{array}$ & $\begin{array}{l}\text { Height } \\
{[\mathrm{pA}]}\end{array}$ & $\begin{array}{c}\text { Area } \\
\frac{\circ}{0}\end{array}$ \\
\hline \multicolumn{7}{|c|}{$-----|-------|----|-------|----------|----------|--------\mid$} \\
\hline 4 & 4.947 & $\mathrm{BB}$ & 0.0438 & 1455.53064 & 474.36819 & 59.91115 \\
\hline 5 & 7.999 & BV & 0.0171 & 271.90131 & 241.69772 & 11.19174 \\
\hline Tota & : & & & 2429.48209 & 1298.53970 & \\
\hline
\end{tabular}

$\star \star \star$ End of Report $\star \star \star$

Figure S29: Typical GC-FID chromatogram for the internal standard determination of yield for bromobenzene. 


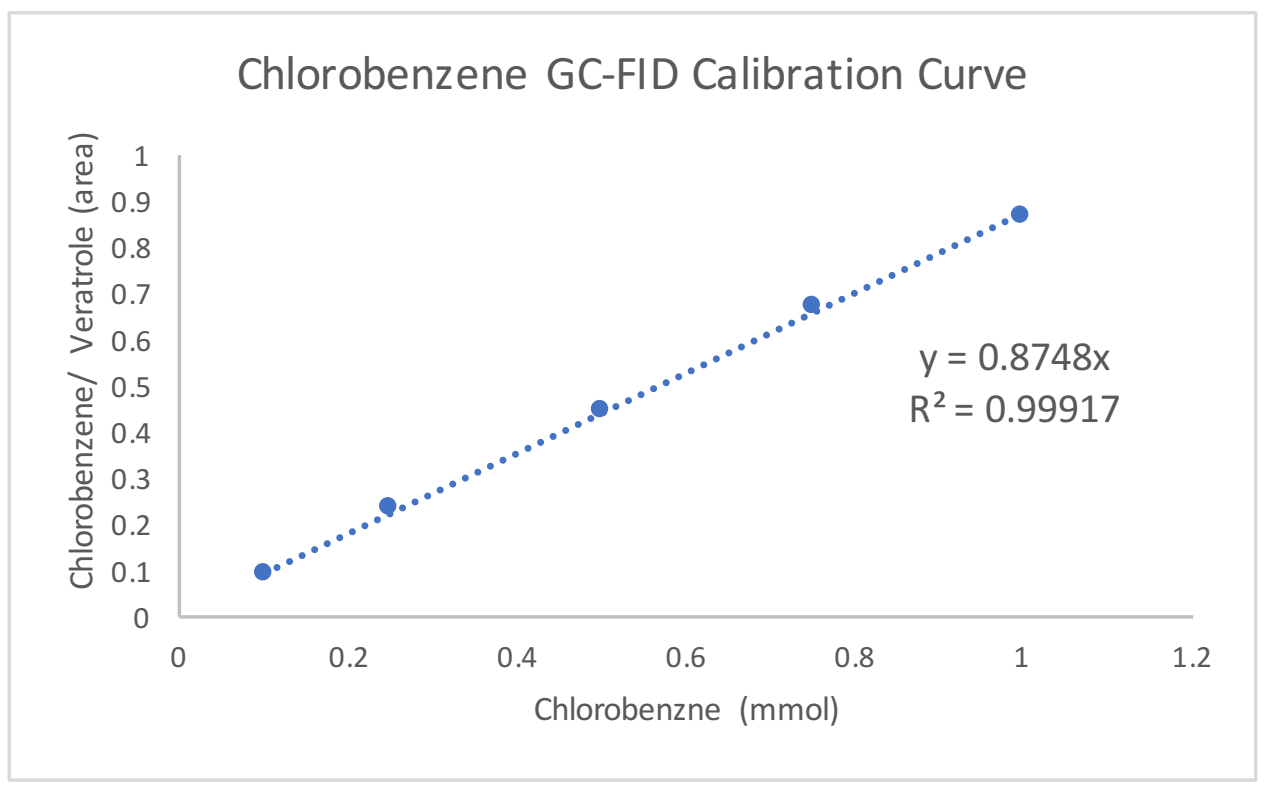

Figure S30: GC-FID calibration curve for the determination of chlorobenzene $(2.1 \mathrm{~min})$ yield with veratrole (7.7 $\mathrm{min})$ as the internal standard, using GC-FID method [60-RAMP]. 
Data File C: \CHEM32\1\DATA \GRAY \GRAY 2019-08-14 18-07-33\WKH4-005-2.D Sample Name: WKH4-005-2
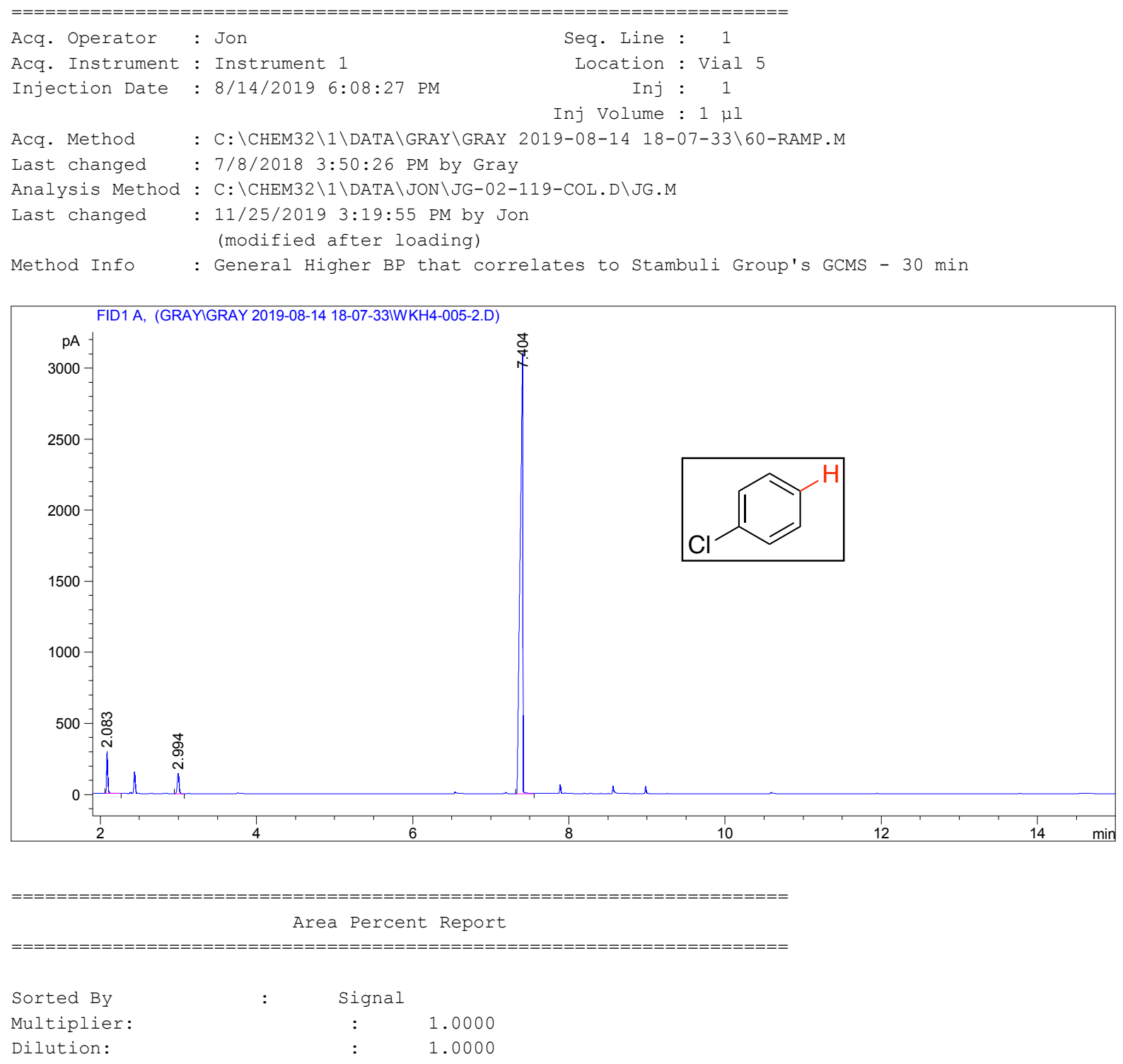

Use Multiplier \& Dilution Factor with ISTDs

Signal 1: FID1 A,

\begin{tabular}{|c|c|c|c|c|c|c|}
\hline $\begin{array}{c}\text { Peak } \\
\#\end{array}$ & $\begin{array}{c}\text { RetTime } \\
\text { [min] }\end{array}$ & Type & $\begin{array}{l}\text { Width } \\
\text { [min] }\end{array}$ & $\begin{array}{c}\text { Area } \\
{\left[\mathrm{pA}^{\star} \mathrm{s}\right]}\end{array}$ & $\begin{array}{l}\text { Height } \\
{[\mathrm{pA}]}\end{array}$ & $\begin{array}{c}\text { Area } \\
\quad \%\end{array}$ \\
\hline- & ----- & - & ------ & |---------- & $\mid-----------$ & -------- \\
\hline 1 & 2.083 & VV & 0.0163 & 308.08041 & 292.17230 & 3.78453 \\
\hline 2 & 2.994 & $\mathrm{VB}$ & 0.0254 & 228.64261 & 141.47766 & 2.80870 \\
\hline 3 & 7.404 & BV & 0.0317 & 7603.78662 & 3088.04297 & 93.40676 \\
\hline
\end{tabular}




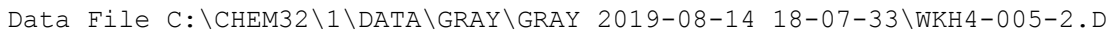

Sample Name: WKH4-005-2

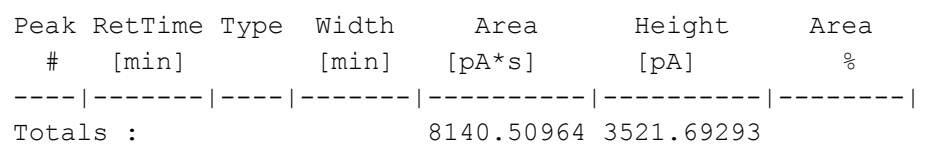

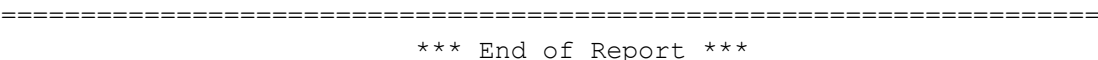

Figure S31: Typical GC-FID chromatogram for the internal standard determination of yield for chlorobenzene. 


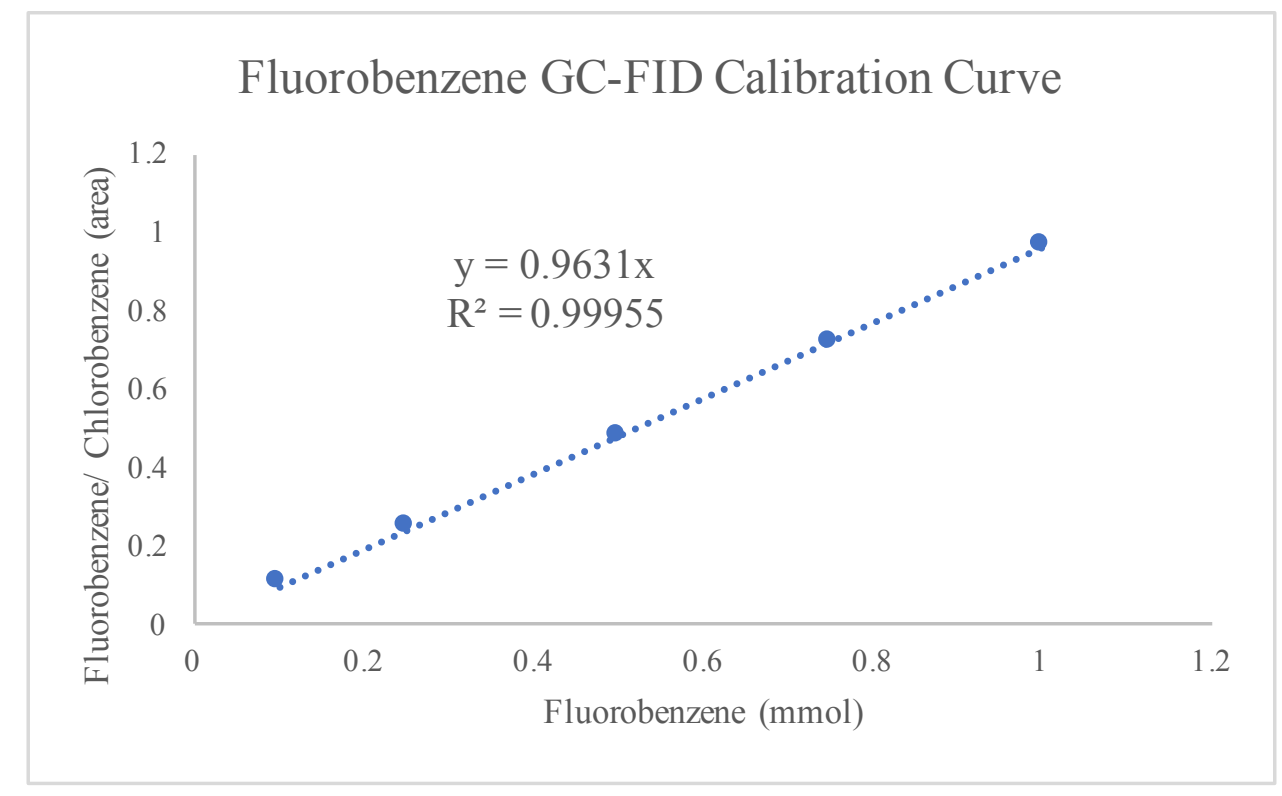

Figure S32: GC-FID calibration curve for the determination of fluorobenzene (1.7 min) yield with chlorobenzene (4.7 min) as the internal standard, using GC-FID method [35-RAMP-B]. 
Data File C: \CHEM32\1\DATA \HAUG \WKH4-092.D

Sample Name: WKH4-092
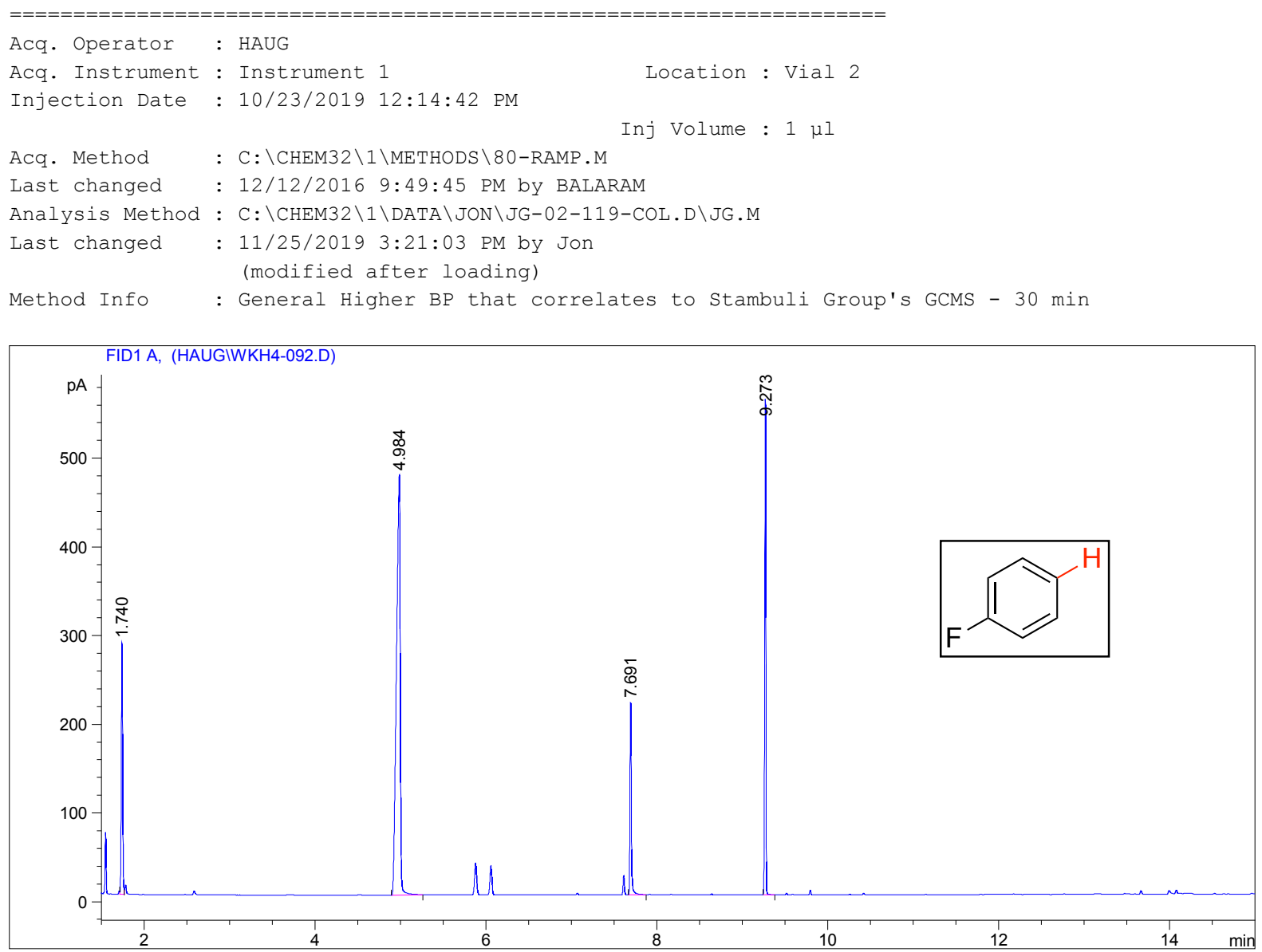

Area Percent Report

\begin{tabular}{|c|c|c|}
\hline Sorted By & : & Signal \\
\hline Multiplier: & & : \\
\hline Dilution: & & : \\
\hline
\end{tabular}

Use Multiplier \& Dilution Factor with ISTDs

Signal 1: FID1 A,

\begin{tabular}{|c|c|c|c|c|c|c|}
\hline $\begin{array}{c}\text { Peak } \\
\quad \#\end{array}$ & $\begin{array}{c}\text { RetTime } \\
\text { [min] }\end{array}$ & Type & $\begin{array}{l}\text { Width } \\
\text { [min] }\end{array}$ & $\begin{array}{r}\text { Area } \\
{\left[\mathrm{pA}^{\star} \mathrm{s}\right]}\end{array}$ & $\begin{array}{l}\text { Height } \\
{[\mathrm{pA}]}\end{array}$ & $\begin{array}{c}\text { Area } \\
\frac{\circ}{0}\end{array}$ \\
\hline--- & & & & |---------- & ---------- & -------- \\
\hline 1 & 1.740 & VV & 0.0167 & 309.34525 & 283.88757 & 12.21666 \\
\hline 2 & 4.984 & $\mathrm{BB}$ & 0.0463 & 1465.21252 & 473.73819 & 57.86416 \\
\hline 3 & 7.691 & $\mathrm{BB}$ & 0.0172 & 241.46596 & 216.97716 & 9.53597 \\
\hline
\end{tabular}


Data File C: \CHEM32\1\DATA \HAUG \WKH4-092.D

Sample Name: WKH4-092

\begin{tabular}{|c|c|c|c|c|c|c|}
\hline $\begin{array}{c}\text { Peak } \\
\#\end{array}$ & $\begin{array}{c}\text { RetTime } \\
\text { [min] }\end{array}$ & Type & $\begin{array}{l}\text { Width } \\
\text { [min] }\end{array}$ & $\begin{array}{r}\text { Area } \\
{\left[\mathrm{pA}^{\star} \mathrm{s}\right]}\end{array}$ & $\begin{array}{l}\text { Height } \\
{[\mathrm{pA}]}\end{array}$ & $\begin{array}{c}\text { Area } \\
\%\end{array}$ \\
\hline 4 & 9.273 & BB & 0.0145 & 516.13525 & 558.99536 & 20.38321 \\
\hline Tota & Ls : & & & 2532.15898 & 1533.59828 & \\
\hline
\end{tabular}

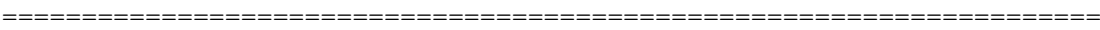

$\star \star \star$ End of Report $\star * \star$

Figure S33: Typical GC-FID chromatogram for the internal standard determination of yield for fluorobenzene. 


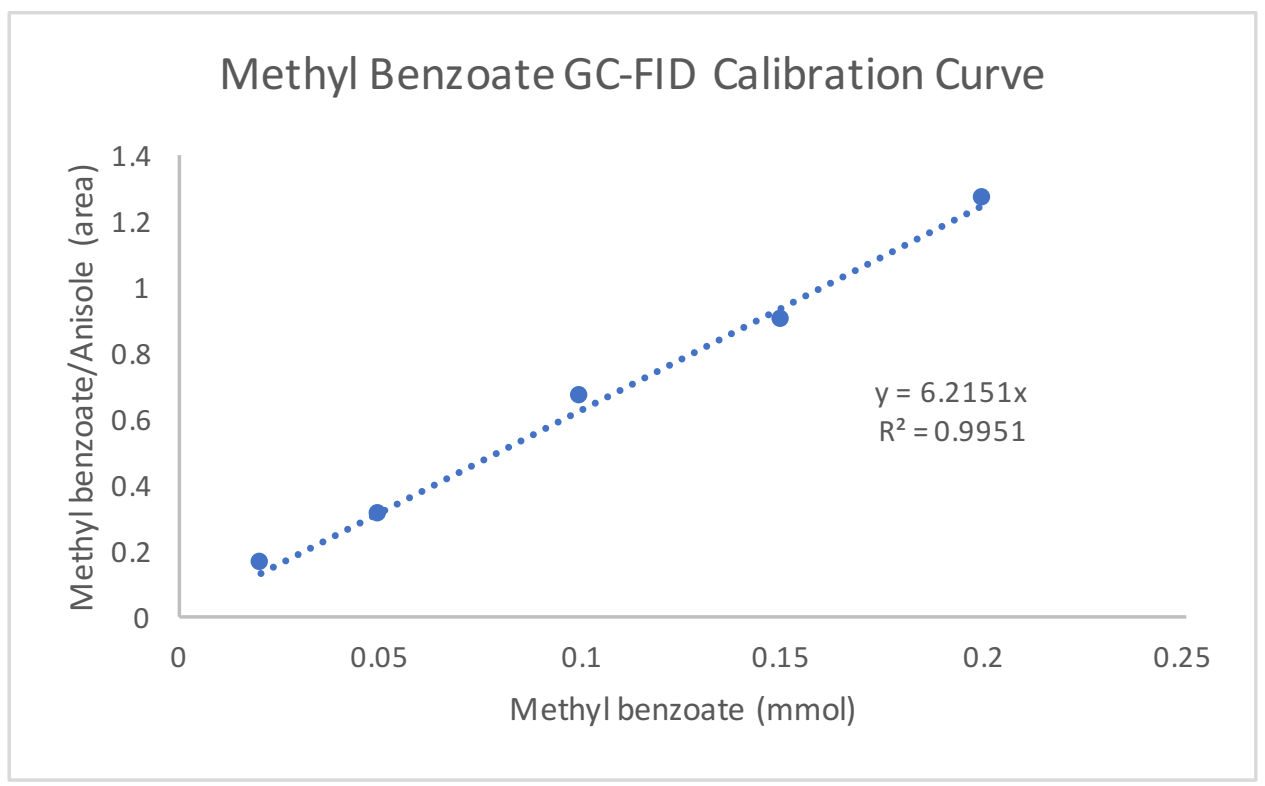

Figure S34: GC-FID calibration curve for the determination of methyl benzoate (3.8 min) yield with anisole (1.7 $\mathrm{min})$ as the internal standard, using GC-FID method [80-RAMP]. 


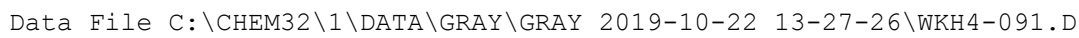

Sample Name: WKH4-091
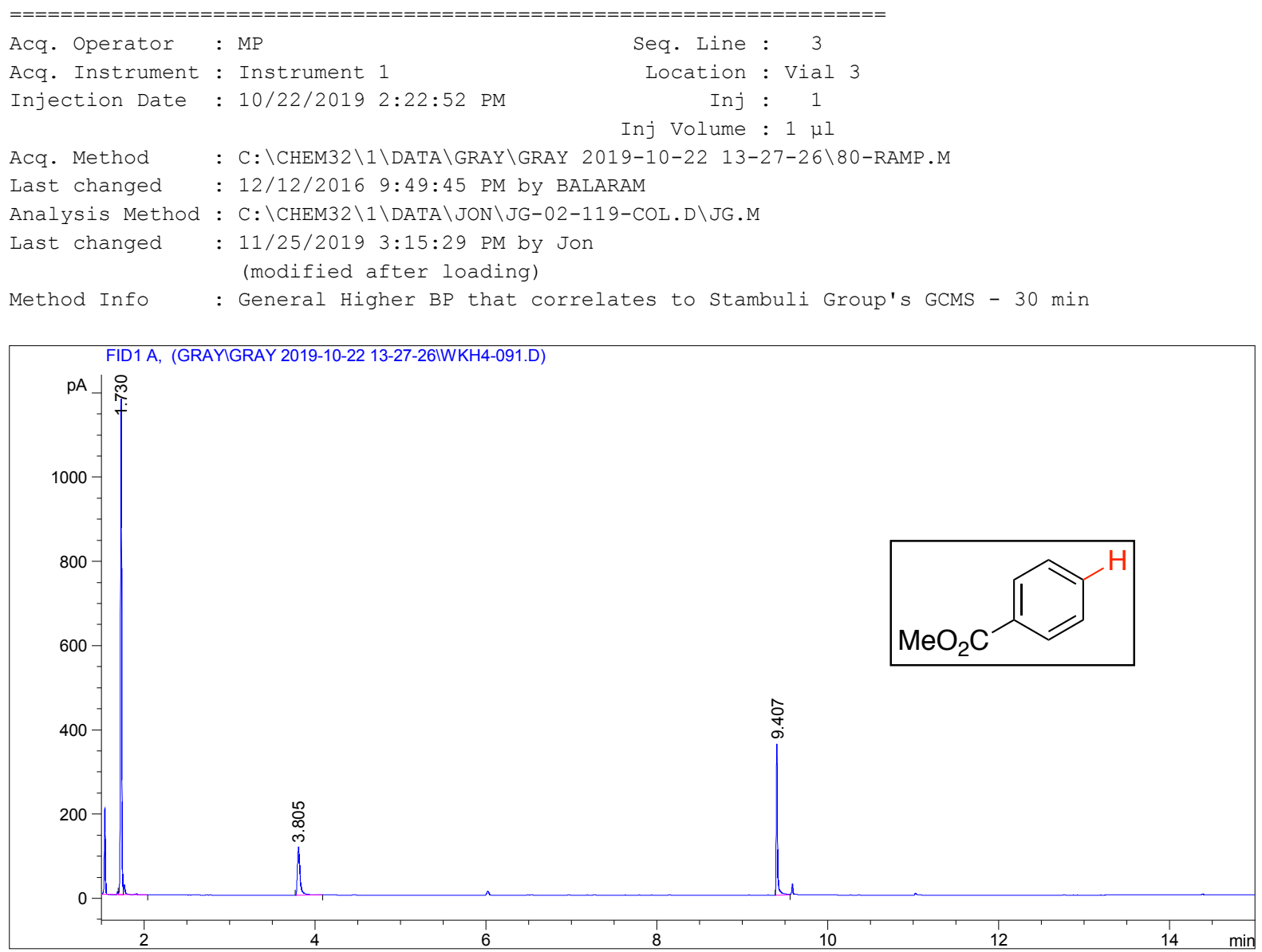

Area Percent Report

\begin{tabular}{|c|c|c|}
\hline Sorted By & : & Signal \\
\hline Multiplier: & & : \\
\hline Dilution: & & : \\
\hline
\end{tabular}

Use Multiplier \& Dilution Factor with ISTDs

Signal 1: FID1 A,

\begin{tabular}{|c|c|c|c|c|c|c|}
\hline $\begin{array}{c}\text { Peak } \\
\#\end{array}$ & $\begin{array}{c}\text { RetTime } \\
\text { [min] }\end{array}$ & Type & $\begin{array}{l}\text { Width } \\
\text { [min] }\end{array}$ & $\begin{array}{r}\text { Area } \\
{\left[\mathrm{pA}{ }^{\star} \mathrm{s}\right]}\end{array}$ & $\begin{array}{l}\text { Height } \\
{[\mathrm{pA}]}\end{array}$ & $\begin{array}{c}\text { Area } \\
\frac{\circ}{0}\end{array}$ \\
\hline & & & & | ---------- & $\mid----------$ & -------- \\
\hline 1 & 1.184 & VB $S$ & 0.0152 & $1.37909 e 5$ & $1.46681 e 5$ & 98.74263 \\
\hline 2 & 1.730 & PV T & 0.0150 & 1137.44971 & 1177.04175 & 0.81442 \\
\hline 3 & 3.805 & $\mathrm{BB}$ & 0.0330 & 246.65860 & 114.06419 & 0.17661 \\
\hline
\end{tabular}




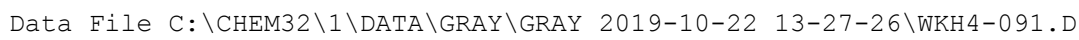

Sample Name: WKH4-091

\begin{tabular}{|c|c|c|c|c|c|c|}
\hline $\begin{array}{c}\text { Peak } \\
\#\end{array}$ & $\begin{array}{c}\text { RetTime } \\
\text { [min] }\end{array}$ & Type & $\begin{array}{l}\text { Width } \\
\text { [min] }\end{array}$ & $\begin{array}{r}\text { Area } \\
{\left[\mathrm{pA}{ }^{\star} \mathrm{s}\right]}\end{array}$ & $\begin{array}{l}\text { Height } \\
{[\mathrm{pA}]}\end{array}$ & $\begin{array}{c}\text { Area } \\
\%\end{array}$ \\
\hline--- & ------- & --- & --ー-ー-- & ----------- & ---------- & -------- \\
\hline 4 & 9.407 & BV & 0.0158 & 371.99780 & 359.85989 & 0.26635 \\
\hline Tota & : & & & $1.39665 e 5$ & $1.48332 e 5$ & \\
\hline
\end{tabular}

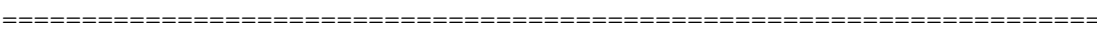

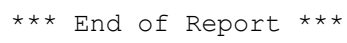

Figure S35: Typical GC-FID chromatogram for the internal standard determination of yield for methyl benzoate. 


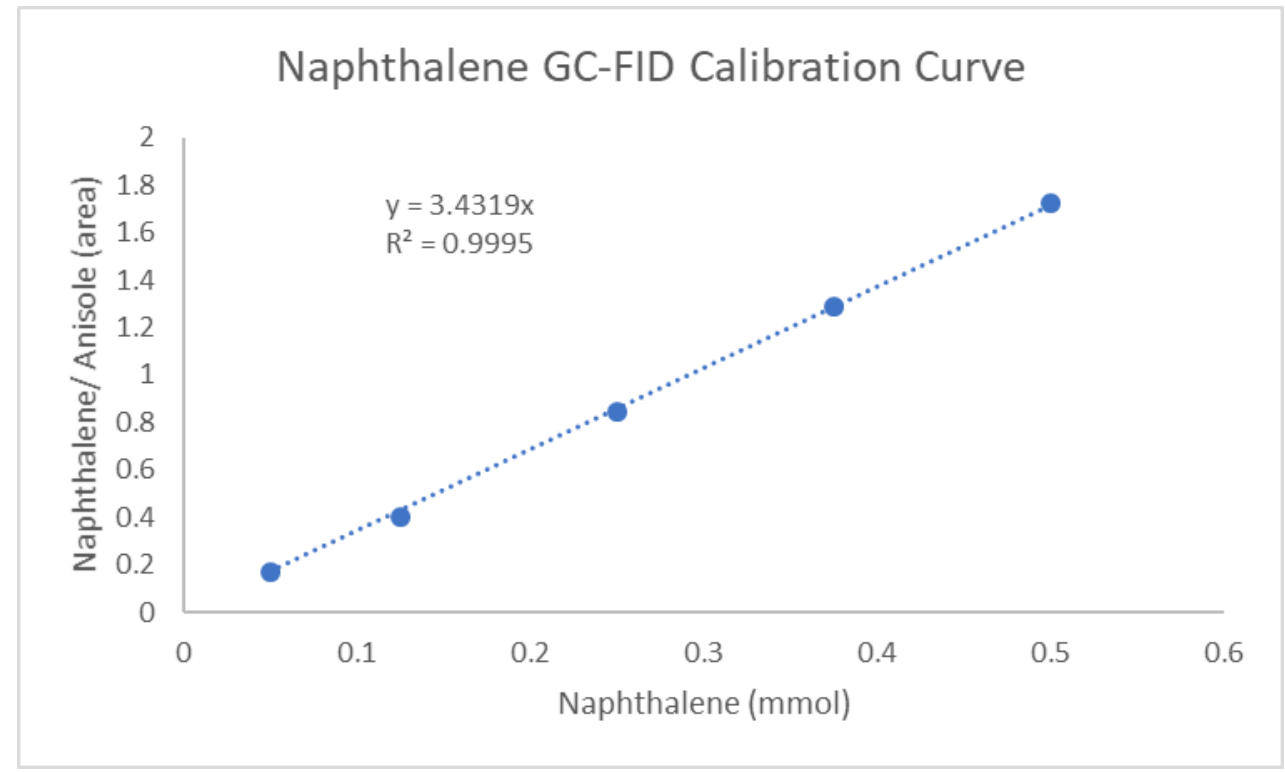

Figure S36: GC-FID calibration curve for the determination of naphthalene (3.1 min) yield with anisole $(1.2 \mathrm{~min})$ as the internal standard, using GC-FID method [100-RAMP]. 
Data File C: \CHEM32\1\DATA \HAUG \WKH4-070.D

Sample Name: WKH4-070

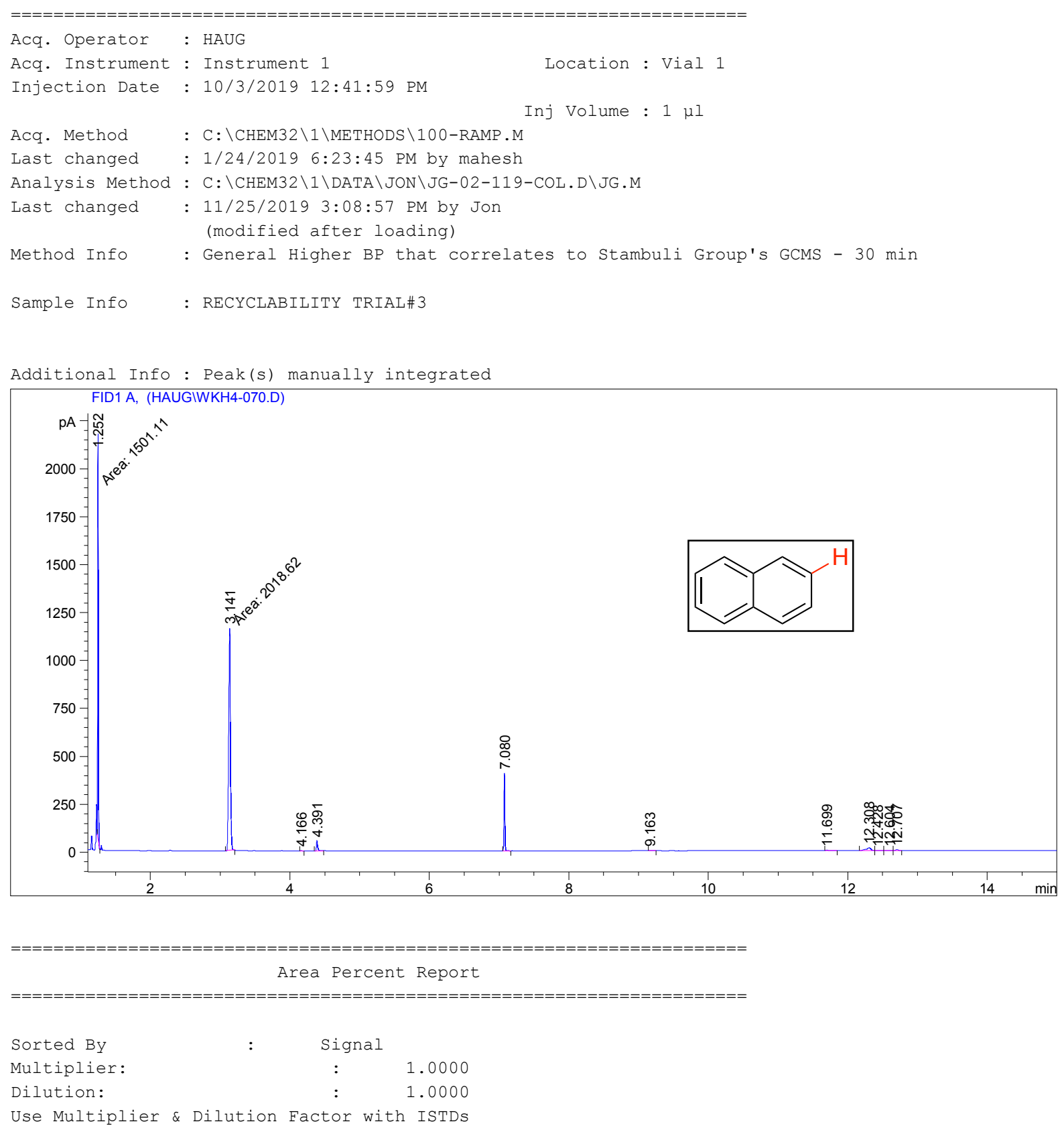


Data File C: \CHEM32\1\DATA \HAUG \WKH4-070.D

Sample Name: WKH4-070

\begin{tabular}{|c|c|c|c|c|c|c|}
\hline $\begin{array}{c}\text { Peak } \\
\quad \#\end{array}$ & $\begin{array}{c}\text { RetTime } \\
\text { [min] }\end{array}$ & Type & $\begin{array}{l}\text { Width } \\
\text { [min] }\end{array}$ & $\begin{array}{r}\text { Area } \\
{\left[\mathrm{pA}^{\star} \mathrm{s}\right]}\end{array}$ & $\begin{array}{l}\text { Height } \\
{[\mathrm{pA}]}\end{array}$ & $\begin{array}{c}\text { Area } \\
\text { \% }\end{array}$ \\
\hline \multicolumn{7}{|c|}{$----|-------|----|-------|----------|----------|--------\mid$} \\
\hline 1 & 1.252 & MM T & 0.0118 & 1501.11389 & 2125.18823 & 36.71688 \\
\hline 2 & 3.141 & MM & 0.0290 & 2018.62341 & 1159.52100 & 49.37503 \\
\hline 3 & 4.166 & VB & 0.0194 & 1.57111 & 1.29971 & 0.03843 \\
\hline 4 & 4.391 & BV & 0.0194 & 68.69982 & 52.82784 & 1.68038 \\
\hline 5 & 7.080 & VB & 0.0145 & 374.79840 & 405.04153 & 9.16748 \\
\hline 6 & 9.163 & $\mathrm{BB}$ & 0.0218 & 2.87087 & 1.93614 & 0.07022 \\
\hline 7 & 11.699 & VB & 0.0439 & 9.64460 & 2.96651 & 0.23590 \\
\hline 8 & 12.308 & BV & 0.0657 & 80.29829 & 15.43391 & 1.96408 \\
\hline 9 & 12.428 & VV & 0.0583 & 6.74936 & 1.54156 & 0.16509 \\
\hline 10 & 12.604 & VV & 0.0522 & 7.25017 & 1.79278 & 0.17734 \\
\hline 11 & 12.707 & VV & 0.0485 & 16.72878 & 5.42877 & 0.40918 \\
\hline Total & Ls : & & & 4088.34871 & 3772.97798 & \\
\hline
\end{tabular}

$\star \star \star$ End of Report $* \star \star$

Instrument 1 11/25/2019 3:09:05 PM Jon

Page 2 of 2

Figure S37: Typical GC-FID chromatogram for the internal standard determination of yield for naphthalene. 


\section{References:}

1. E. R. Wolfson, N. Xiao, L. Schkeryantz, W. K. Haug, Y. Wu and P. L. McGrier, Mol. Syst. Des. Eng., 2020, 5, 97-101.

2. J. D. Ferrara, C. Tessier-Youngs and W. J. Youngs, J. Am. Chem. Soc., 1985, 107, 67196721.

3. F. Luo, C. Pan, L. Li, F. Chen and J. Cheng, Chem. Commun., 2011, 47, 5304-5306.

4. Y. Uetake, T. Niwa and T. Hosoya, Org. Lett., 2016, 18, 2758-2761.

5. R. Rahil, S. Sengmany, E. L. Gall and E. Léonel, Synthesis, 2017, 50, 146-154.

6. M. J. West and A. J. B. Watson, Org. Biomol. Chem., 2019, 17, 5055-5059.

7. M. J. Frisch, G. W. Trucks, H. B. Schlegel, G. E. Scuseria, M. A. Robb, J. R. Cheeseman, G. Scalmani, V. Barone, B. Mennucci, G. A. Petersson, H. Nakatsuji, M. Caricato, X. Li, H. P. Hratchian, A. F. Izmaylov, J. Bloino, G. Zheng, J. L. Sonnenberg, M. Hada, M. Ehara, K. Toyota, R. Fukuda, J. Hasegawa, M. Ishida, T. Nakajima, Y. Honda, O. Kitao, H. Nakai, T. Vreven, J. Montgomery, J. A., J. E. Peralta, F. Ogliaro, M. Bearpark, J. J. Heyd, E. Brothers, K. N. Kudin, V. N. Staroverov, T. Keith, R. Kobayashi, J. Normand, K. Raghavachari, A. Rendell, J. C. Burant, S. S. Iyengar, J. Tomasi, M. Cossi, N. Rega, J. M. Millam, M. Klene, J. E. Knox, J. B. Cross, V. Bakken, C. Adamo, J. Jaramillo, R. Gomperts, R. E. Stratmann, O. Yazyev, A. J. Austin, R. Cammi, C. Pomelli, J. W. Ochterski, R. L. Martin, K. Morokuma, V. G. Zakrzewski, G. A. Voth, P. Salvador, J. J. Dannenberg, S. Dapprich, A. D. Daniels, Ö. Farkas, J. B. Foresman, J. V. Ortiz, J. Cioslowski and D. J. Fox, Gaussian, 2013.

8. A. D. Becke, Phys. Rev. A: At. Mol. Opt. Phys., 1988, 38, 3098-3100.

9. J. P. Perdew, Phys. Rev. B: Condens. Matter, 1986, 33, 8822-8824.

10. P. J. Hay and W. R. Wadt, J. Chem. Phys., 1985, 82, 299-310.

11. L. E. Roy, P. J. Hay and R. L. Martin, J. Chem. Theory Comput., 2008, 4, 1029-1031.

12. P. J. Hay and W. R. Wadt, J. Chem. Phys., 1985, 82, 270-283.

13. J. D. Ferrara, C. Tessier-Youngs and W. J. Youngs, J. Am. Chem. Soc., 1985, 107, 67196721. 